\title{
Three endemic Aphaenogaster from the Siculo-Maltese archipelago and the Italian Peninsula: part of a hitherto unrecognized species group from the Maghreb? (Hymenoptera: Formicidae: Myrmicinae)
}

\author{
Antonio ALICATA ${ }^{1)} \&$ Enrico SCHIFANI2,,*) \\ 1) Via Passo Gravina 245/12, I-95125, Catania, Italy; e-mail: antonioalicata@gmail.com \\ ${ }^{2)}$ Section Animal Biology, Department STEBICEF, University of Palermo - Via Archirafi 18, I-90123, Palermo, Italy; ORCID iD: https://orcid. \\ org/0000-0003-0684-6229; e-mail: enrsc8@gmail.com \\ *) corresponding author
}

Accepted:
10
th January 2019

Published online: $28^{\text {th }}$ January 2019

\begin{abstract}
More than 100 years ago, the Italian myrmecologist Carlo Emery described two endemic Sicilian ants: Aphaenogaster sicula Emery, 1908, which he originally considered a subspecies of A. crocea André, 1881, and A. fiorii Emery, 1915 stat. nov., which he believed was a subspecies of $A$. gibbosa (Latreille, 1798). Males of the two species and the queen of $A$. fiorii were never described. The scarcity of information contained in the original description led to several misunderstandings by subsequent authors: for example, $A$. sicula was later elevated to species-rank on the basis of misidentified material of $A$. fiorii stat. nov. We redescribe the two species, adding the descriptions of their missing castes and designating their lectotypes. We also describe a third related species of the genus: A. trinacriae sp. nov. from Sicily. The ecology and distribution of the three are illustrated. Their relationship with the other congeneric species of the Mediterranean basin is discussed considering the morphology of all three castes, with attention to the often-overlooked males. Despite the fact that $A$. fiorii and A. sicula were lately believed to be close relatives of A. subterranea (Latreille, 1798), the morphological elements available suggest that they probably belong to a separate, hitherto unrecognized clade from the Maghreb (North-Western Africa), together with A. trinacriae sp. nov.
\end{abstract}

Key words. Hymenoptera, Formicidae, Stenammini, allopatric speciation, ant males, biogeography, Mediterranean basin, Palaearctic Region

Zoobank: http://zoobank.org/urn:1sid:zoobank.org:pub:0EA032E4-230F-45DF-BDEB-6ACEA88AF418

(C) 2018 The Authors. This work is licensed under the Creative Commons Attribution-NonCommercial-NoDerivs 3.0 Licence.

\section{Introduction}

The genus Aphaenogaster Mayr, 1853 includes about 200 species and 25 subspecies which are present in all continents but absent from the Afrotropical Region and from most of the Neotropical Region (ANTweb 2018). It belongs to the tribe Stenammini Ashmead, 1905 along with the mostly Holarctic genus Stenamma Westwood, 1839, the genus Messor Forel, 1890 from Africa and Eurasia, the Nearctic Novomessor Emery, 1915 and Veromessor Forel, 1917, the Mediterranean endemics Goniomma Emery, 1895 and Oxyopomyrmex André, 1881, and the fossil genus $\uparrow P a-$ raphaenogaster Dlussky, 1981 (WARD et al. 2014). While in the past the species of the genus were organized into subgenera, this system is no longer in use (since BOLTON 1995). No comprehensive revision of the genus Aphaenogaster exists, still recent investigations have proved it to be polyphyletic, comprising at least four different lineages (WARD 2011, WARD et al. 2014, BRANSTETtER et al. 2016).

A total of 83 species of Aphaenogaster are known from the Mediterranean basin and adjacent regions (BOROwIEC 2014). Two centers of biodiversity are recognized in the area, namely the Maghreb (North-Western Africa) and the Eastern Mediterranean basin (Borowiec \& Salata 2014). Many of the Mediterranean species were included in spe- 
cies groups defined on the basis of worker's morphology by SCHulz (1994) and BoER (2013): the A. gibbosa-group (recently redefined by SALATA \& Borowiec 2018a), the $A$. obsidiana-group, $A$. pallida-group, $A$. splendida-group, $A$. subterranea-group, and the $A$. testaceopilosa-group (the latter studied by BOER 2013 on all three castes). More recently the $A$. cecconii-group was established by BOROwIEC \& SALATA (2014), who however expressed uncertainty about its monophyletic origin. A study of the relationships with congeneric species has never been attempted for several other Mediterranean Aphaenogaster. Since BoER (2013) defined Aphaenogaster as a 'forgotten' genus in Europe, not many advancements have been achieved. Lately, the few molecular indications available even led to question if all the Mediterranean ant species currently attributed to Aphaenogaster truly belong to only one genus (Gómez et al. 2018).

Among today's less known Mediterranean Aphaenogaster taxa, two were described from Sicilian material over a century ago by the Italian myrmecologist Carlo Emery: A. crocea sicula Emery, 1908 (type locality is Monte Pellegrino) and A. gibbosa fiorii Emery, 1915 (type locality is Nicolosi). However, their descriptions provided very little information to distinguish them from other similar species and very little information on them was added by subsequent authors. Aphaenogaster sicula was elevated to species-rank by Schembri \& CollingwoOd (1981), but later Scupola (2009) speculated that in the future it might be considered a junior synonym of $A$. subterranea (Latreille, 1798). Aphaenogaster sicula was also considered part of the A. subterranea-group, together with A. crocea André, 1881, by Boer (2013). On the other hand, the status of $A$. gibbosa fiorii did not change until very recently (SALATA \& BorowIEC 2018a), when it was assigned to the $A$. subterranea-group and recombined as $A$. subterranea fiorii. It is important to note that $A$. subterranea is currently under revision, since multiple different entities have been discovered under this name (Borowiec \& Salata 2017). While many other authors have published new faunistic data of A. sicula since EMERY's (1908) work (KUTTER 1927; Bernard 1958; Baroni Urbani 1964, 1968; SChEMBri \& Collingwood 1981; Scupola 2009; Li Vigni 2014), the presence of A. subterranea fiorii was recorded only once after its original description (GRANDI 1935).

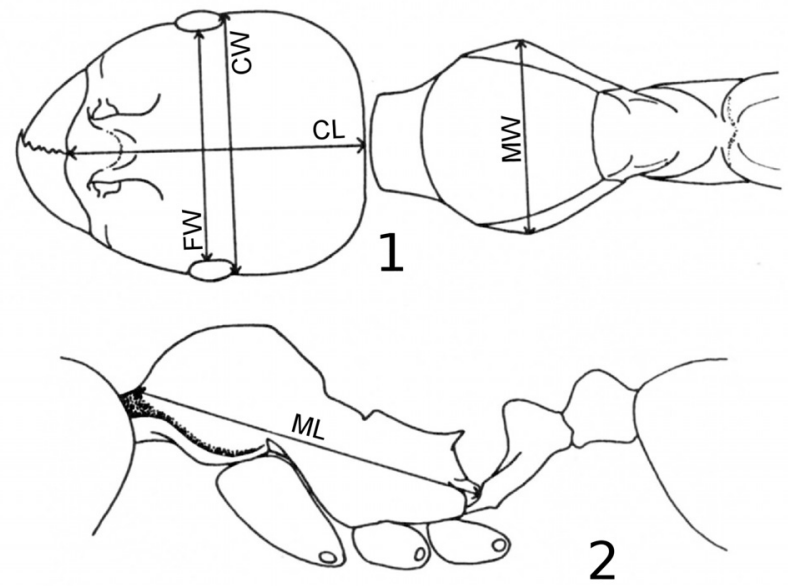

Figs 1-2. Measurement lines for the morphometric characters.
The present study aims to clarify the identity of $A$. fiorii stat. nov. and $A$. sicula by providing redescriptions of their worker caste and descriptions of the previously unknown males and queens. Their distribution and ecological traits are also investigated and defined better. Moreover, we discovered and describe a third Sicilian species, A. trinacriae sp. nov., which represents a similar, yet clearly distinct, taxon. Finally, we used distribution data and morphological evidences to infer the biogeographical and phylogenetic relationships of the three entities.

\section{Material and methods}

Specimens were studied under a Leica Wild M3B stereoscopic microscope, with a micrometric optic used to obtain biometrics at a $40 \times$ magnification. Drawings of male genitals, previously included in Euparal, were obtained through the use of a Leica DMLB optical microscope and a camera lucida at a $150 \times$ magnification. Images of specimens were taken using a Canon 1300D reflex and MP-E $65 \mathrm{~mm} \mathrm{f} / 2.81-5 \times$ Macro Photo lens. Helicon Focus 6.7.1, method $\mathrm{C}$, was used to fuse images taken at different focal planes into single images with greater depth of field. Distribution maps were obtained using the geographic coordinates of the examined material and QGIS 3.2 software. Sexuals were partly obtained by rearing captive colonies of the three species.

Material from the following collections was examined:

AACI Antonio Alicata personal collection, Catania, Italy; ESPI Enrico Schifani personal collection, Palermo, Italy; MHNG Museum d'Historie Naturelle, Geneva, Switzerland; MSNG Museo Civico di Storia Naturale "G. Doria", Genova, Italy; MSNM Museo Civico di Storia Naturale, Milano, Italy; MSNV Museo Civico di Storia Naturale, Verona, Italy; MZLS Musée Zologique, Lausanne, Switzerland; SSLM Stephen Schembri personal collection, La Valletta, Malta.

Measurements are expressed in mm and values as mean \pm standard deviation (minimum - maximum).

CL Cephalic length, the length of the head capsule excluding the mandibles, measured in full face view in a straight line from the mid-point of the anterior clypeal margin to the mid-point of the posterior margin. (Fig 1).

CW Cephalic width, the maximum width of the head in full face view, measured posteriorly to level of eyes. (Fig 1).

CI Cephalic index, calculated as CW $\times 100 / C L$.

FW Frons width, the minimum distance between eyes in full face view (Fig 1).

ML Mesosoma length, the diagonal length of the mesosoma in profile from the point where the pronotum meets the cervical shield to the posterior basal angle of the propodeal lobe (Fig 2).

MW Mesosoma width, the maximum width of the mesosoma in dorsal view (Fig 1).

SL Scape length, the maximum straight-line length of the scape, excluding the basal constriction or neck that occurs just distal of the condylar bulb.

SI Scape index, calculated as $\mathrm{SL} \times 100 / \mathrm{CW}$.

The degree of inclination of pilosity follows HöLLDOBLER \& WiLSON (1990): adpressed $\left(0-5^{\circ}\right)$ hairs run parallel, or nearly parallel to the body surface; decumbent hairs stand $10-15^{\circ}$; subdecumbent hair stands $30^{\circ}$; suberect hairs stand $35-45^{\circ}$; and erect hairs stand more than $45^{\circ}$ from the body surface. 


\section{Results}

\section{Aphaenogaster fiorii Emery, 1915 stat. nov.}

Published records (excluding bibliographic checklists). As $A$. gibbosa fiorii in EMERY (1915) (type material - examined) and as A. fiorii in Alicata (1999).

Misidentified as A. crocea sicula in BARONI URBANI (1968) (material examined), as A. sicula in Schembri \& Collingwood (1981) (material examined)

Material published by GRANDI (1935) could not be examined.

Type material examined. Lестотуре (here designated): $1 \circlearrowleft$, Sicilia / Nicolosi / 24.IV.'912 / leg. A. Fiori // Aphaen. gibbosa fiorii Emery (handwritten) // LECTOTYPUS / des. Alicata \& Schifani 2018 // Coll. C. Emery / Museo Genova // ANTWEB / CASENT0904175 // Aphaenogaster fiorii / det. Alicata \& Schifani 2018 [Nicolosi (CT) - MSNG] Paralectotype: $1 \stackrel{q}{\text {, }}$ Sicilia / Nicolosi / 24.IV.'912 / leg. A.Fiori // PARALECTOTYPUS / des. Alicata \& Schifani 2018 // Coll. C. Emery / Museo Genova // Aphaenogaster fiorii / det. Alicata \& Schifani 2018

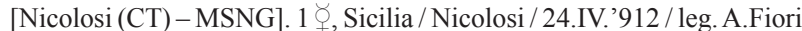
// Aphaen. gibbosa fiorii Emery // PARALECTOTYPUS / des. Alicata \& Schifani 2018 // Coll. A. Forel // Aphaenogaster fiorii / det. Alicata \& Schifani 2018 [Nicolosi (CT) - MHNG].

Additional material examined. Maltese Islands: Mgarr, Gozo, 23.iv.1965, leg. C. Baroni Urbani, sub. A. crocea sicula (BARONI URBANI 1968) (MSNV); Mistra, Malta, 22.iv.1965, leg. C. Baroni Urbani, sub. A. crocea sicula (BARONI URBANI 1968) (MSNM, MSNV); Buskett, Malta, 15.iv.1965, leg. C. Baroni Urbani, sub. A. crocea sicula (BARONI URBANI 1968) (MSNV); Tal-Blata (Selmun), Malta, 04.ix.1978, leg. S.P. Schembri, sub A. sicula (SCHEMBRI \& Collingwood 1981) (SSLM); Buskett, Malta, vi.1975, vi.1976, ix.1976, leg. S. P. Schembri, sub A. sicula (ScHEMBRI \& Collingwood 1981) (SSLM); Ghajn Tuffieha, Malta, 27.xii.1975, sub A. sicula (Schembri \& Collingwood 1981), leg. S. P. Schembri (SSLM); Wied Qannotta, Malta, 25.iii.1978, sub A. sicula (Schembri \& Collingwood 1981), leg. S. P. Schembri (SSLM); Dingli, Buskett, Malta, mixed forest, 29.x.1997, leg. A. Alicata (AACI); Golden Bay, Mgarr, Malta Mediterranean maquis, 31.x.1997, leg. A. Alicata (AACI); Golden Bay, Mgarr, Gozo, Malta, meadow, 31.x.1997, leg. A. Alicata (AACI); San Blas, Gozo, Malta, 36 $03^{\prime} 22.20^{\prime \prime} \mathrm{N}, 14^{\circ} 18^{\prime} 04.39^{\prime \prime} \mathrm{E}$, area populated by marginal synanthropic vegetation near crops, 19.xi.2017, $25 \mathrm{~m}$, leg. R. Viviano (ESPI); Marfa, Malta, 3559'12.78"N 14¹9'51.26"E, 5 m, small area populated by Limonium melitense between a road and a sandy beach in a touristic area, 19.xi.2017, leg. A. Dentici (ESPI). ITALY: SICILY: Pendici M. Pagano, Caronia (ME), Sicily, Italy, Quercus suber forest, 300 m, 07.xi.1987, pitfall traps, leg. D. Caruso (AACI); F. S. Paolo, Francavilla (ME), Sicily, Italy, 37 $56^{\prime} 30.27^{\prime \prime} \mathrm{N}, 15^{\circ} 5^{\prime} 57.81^{\prime \prime} \mathrm{E}, 500 \mathrm{~m}$, deciduous forest of the Ouercus pubescens group, 28.vi.1993, leg. A. Alicata (AACI, MSNM); V.ne Calcinara, Sortino (SR), Sicily, Italy, $37^{\circ} 8^{\prime} 40.50^{\prime \prime} \mathrm{N}, 14^{\circ} 56^{\prime} 56.98^{\prime \prime} \mathrm{E}, 565 \mathrm{~m}$, deciduous forest of the Quercus pubescens group, 25.vii.1995, leg. A. Alicata (AACI); Bosco S. Maria La Stella, Aci S. Antonio (CT), Sicily, Italy, 37³8'3.62"N, 15²'1.04"E, 395 m, deciduous forest of the Quercus pubescens group, 10.iii.1997, leg. A. Alicata (AACI); Palazzolo Acreide (SR), Sicily, Italy, private garden near the archaeological area, 5.vi.1998, leg. A. Alicata (AACI); Bosco di Bauli, Noto (SR), Sicily, Italy, 3701'53.28"N, 1456'21.57"E, 620 m, Quercus ilex forest, 12.vii.1998, leg. A. Alicata (AACI); Pratofiorito, Adrano (CT), Sicily, Italy, $37^{\circ} 42^{\prime} 59.90^{\prime \prime} \mathrm{N}, 14^{\circ} 52^{\prime} 5.17^{\prime \prime} \mathrm{E}, 1,000 \mathrm{~m}$, Quercus ilex forest, 18.v.2002, leg. G. Carcò (AACI); R.N.O. Grotta Conza (PA), Sicily, Italy, mixed forest, 27.vi.2006, pitfall traps, leg. R. Grasso (AACI); Buonriposo (EN), Sicily, Italy, $37^{\circ} 36^{\prime} 20.0^{\prime \prime} \mathrm{N}, 14^{\circ} 14^{\prime} 41.4^{\prime \prime} \mathrm{E}, 700 \mathrm{~m}$, Quercus pubescens group, pitfall trap, 6.xi.2007, leg. A. Alicata (AACI).

Worker redescription (Figs 3, 4, 9, 12, 13). Measurements and indices (42 individuals, 8 localities): HL: $1.14 \pm 0.06$ (1.05-1.27); HW: $0.97 \pm 0.07$ (0.82-1.15); CI: $85.28 \pm 2.66$ (78.57-93.75); FW: $0.85 \pm 0.06(0.75-1.00)$; SL: $1.23 \pm$ 0.6 (1.12-1.37); SI: $126.48 \pm 4.93$ (117.77-139.39); MW: $0.61 \pm 0.04(0.52-0.75)$; ML: $1.53 \pm 0.08$ (1.37-1.75). Whole body yellow except for first gastral segment which is darker. Head subrectangular, lateral margins under eyes slightly rounded, posterior margin of head straight. Anterior margin of clypeus gradually convex, mandibles rounded. Antennae with twelve segments, antennal club with four segments. Promesonotal suture only slightly marked, the two forming almost continuous dorsal profile in lateral view. In lateral view dorsal profile of metanotum presents slight depression or it is straight. Dorsal profile of propodeum mostly straight, spines variable in size but always well-defined, often oriented upwards. Sculpture relatively weak and shiny in general. Head finely reticulated with longitudinal striae mostly limited to lateral areas under eyes, sparsely present above eyes and variably on mandibles. Mesepisternum and propodeum reticulated with fine longitudinal striae, pronotum finely imbricate, gaster smooth, petiole and postpetiole finely imbricate to reticulate. Suberect and erect setae sparse all over head, decumbent setae on mandibles, adpressed setae on scapes and adpressed to subdecumbent setae on flagellomeres. Long setae extending down from clypeus. Erect setae over dorsal surface of mesosoma, petiole and postpetiole, and all over gaster. Mostly adpressed, partly suberect setae on legs, with sparse erect setae on coxae and femora.

Male description (Figs 20, 21, 26, 29, 30). Measurements and indices ( 3 individuals, 1 locality): HL: 0.68 \pm 0.01 ; HW: $0.72 \pm 0.02$; CI: $106.12 \pm 4.31$; FW: 0.46 \pm 0.01 ; SL: $0.20 \pm 0.00$; SI: $27.60 \pm 0.95$; MW: $0.82 \pm$ 0.02; ML: $1.67 \pm 0.04$. Whole body yellowish except for head which is dark brown. All appendages paler than rest of body. Head subtrapezoidal, occipital margin rounded, anterior margin of clypeus convex, eyes large and oval. Antennae with thirteen segments, antennal club with five segments. Mesosoma elongated, with anterior gibbous part formed by prothorax, mesothorax and part of metathorax, and posterior part comparatively flat formed by part of metathorax and propodeum. Promesonotal suture well marked, pronotum and mesonotum convex in lateral view, rounded on side. Metathorax arched, consisting of subvertical and subhorizontal part. Subhorizontal part, in dorsal view, becomes very narrow in proximity of subvertical part. Propodeum not much thicker than horizontal part of metathorax in lateral view. Propodeal spines are absent and only represented by two tubercles. Petiole elongated, petiolar node and postpetiolar node rounded, both dorsally presenting shallow longitudinal suture in center. Scape very short, covered by rare decumbent setae, decumbent to subdecumbent setae also present on head, mesosoma and legs, a few erect setae on mesosoma, coxae, petiole and postpetiole and suberect to erect setae on gaster. Head finely reticulated, rest of body smooth and shiny.

Queen description (Figs 35, 36, 41). Measurements and indices (4 individuals, 2 localities): HL: $1.48 \pm 0.04$; HW: $1.46 \pm 0.03$; CI: $98.75 \pm 0.01$; FW: $1.25 \pm 0.04$; SL: 1.42 \pm 0.04 ; SI: $97.42 \pm 1.01$; MW: $1.35 \pm 0.03$; ML: $2.53 \pm$ 0.04 . Whole body yellowish, with darker areas on gaster. Head subrectangular, lateral surface below eyes slightly rounded, posterior margin of head straight. Anterior margin of clypeus slightly convex, mandibles rounded. Antennae with twelve segments, antennal club with four segments. Pronotum rounded in dorsal view, propodeal spines rela- 
tively long, horizontal and with wide base. Petiole with long peduncle and node convex on both sides, postpetiole with anterior concave side and posterior slightly convex side. Entire head, except clypeus and occipital margin, densely covered with longitudinal striae. Long and more marked striae are subparallel to each other. Between them, less marked striae can be found often crossing each other. Mesosoma mostly shiny, with horizontal striae appearing in proximity of sutures, across propodeum and posterior faces of petiole and postpetiole. Adpressed to decumbent
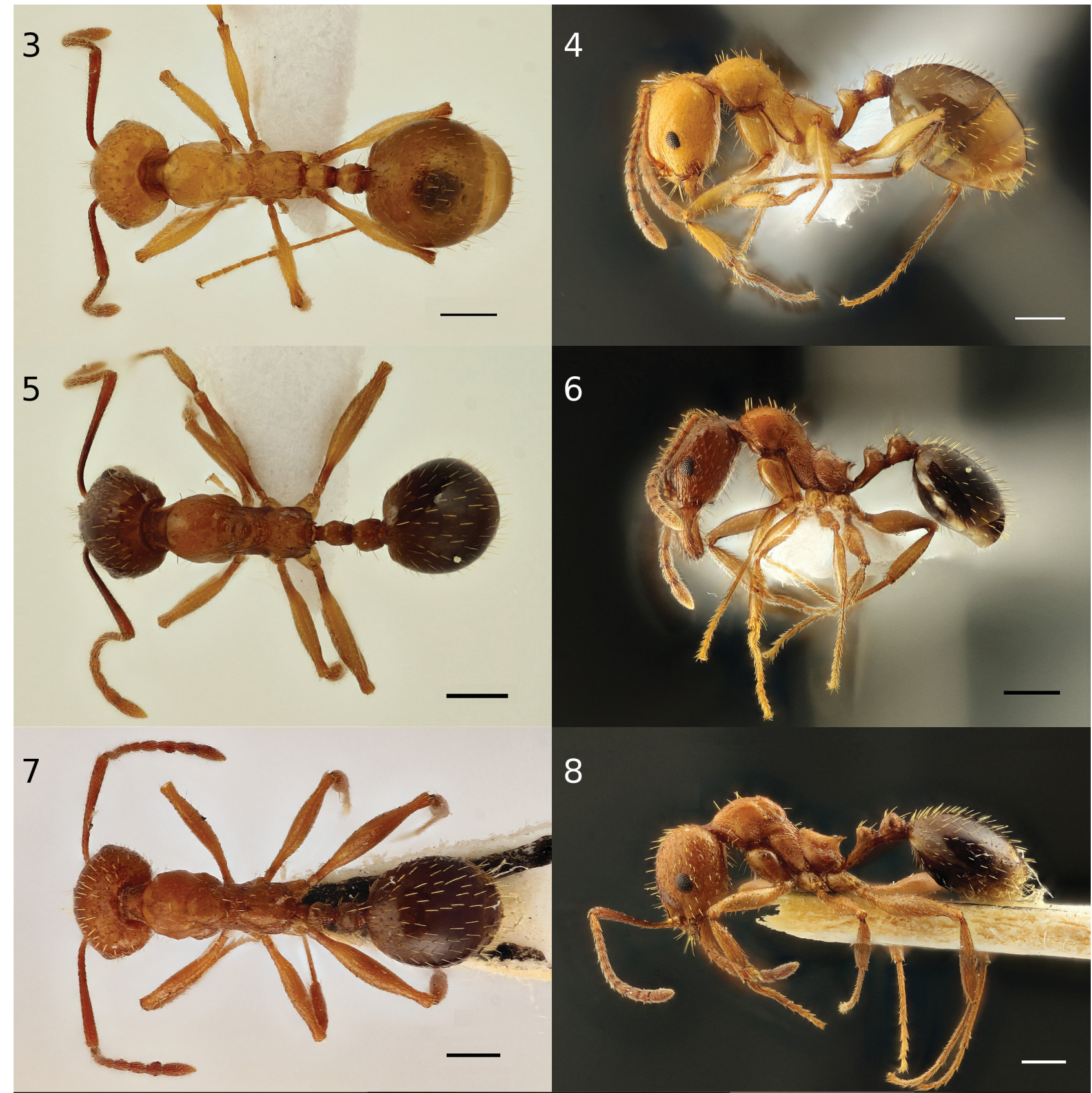

8

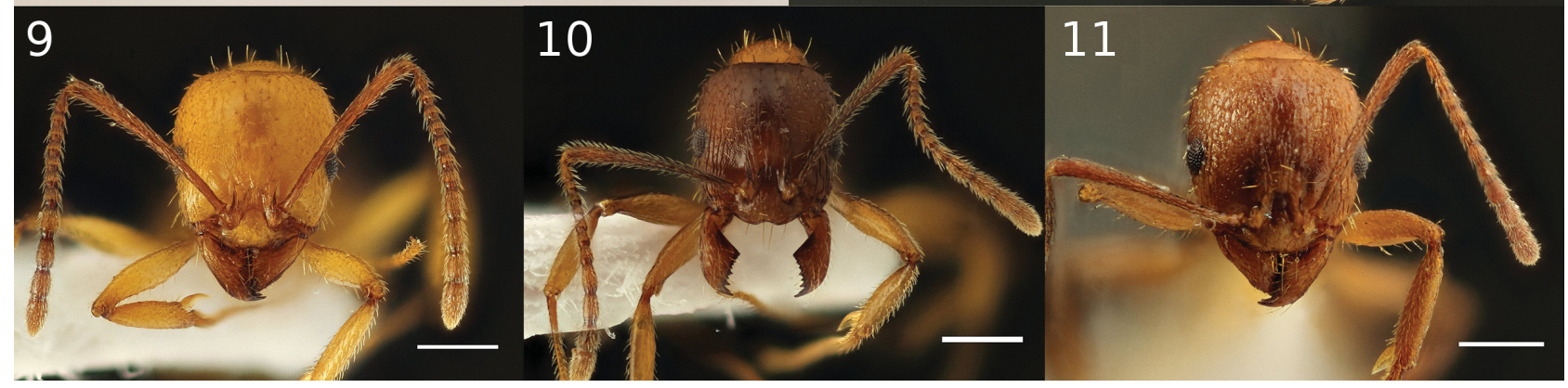

Figs 3-11. Workers in dorsal, lateral and head view (scale bar: $0.50 \mathrm{~mm}$ ): 3, 4, 9-Aphaenogaster fiorii Emery, 1915, stat. nov., non-type worker from Malta; 5, 6, 10 - A. sicula Emery, 1908, non-type worker from M. Pellegrino, Sicily, Italy (type locality); 7, 8, $11-$ A. trinacriae sp. nov., holotype worker AACI-ANTP001/1 from M. Sparagio, Sicily, Italy. Photos by Enrico Schifani. 
setae on antennae, suberect to mostly erect setae on head, dorsal part of mesosoma, of petiole and postpetiole and all over gaster. Long setae extending down from clypeus. Adpressed to decumbent setae on legs.

Systematic position. Aphaenogaster fiorii stat. nov. was originally described by EMERY (1916) as a subspecies of $A$. gibbosa (Latreille, 1798), until SALATA \& Borowiec (2018a) recombined it as $A$. subterranea fiorii. They excluded $A$. fiorii stat. nov. from the gibbosa species group on the basis of its body color, head shape, funicular segments, and length of the scape, claiming that these same characters instead make it part of the A. subterranea species group. Due to the degree of morphological differences from any other congeneric species, relevant in all three castes (see also comparative diagnosis), we consider $A$. fiorii stat. nov. a bona species.
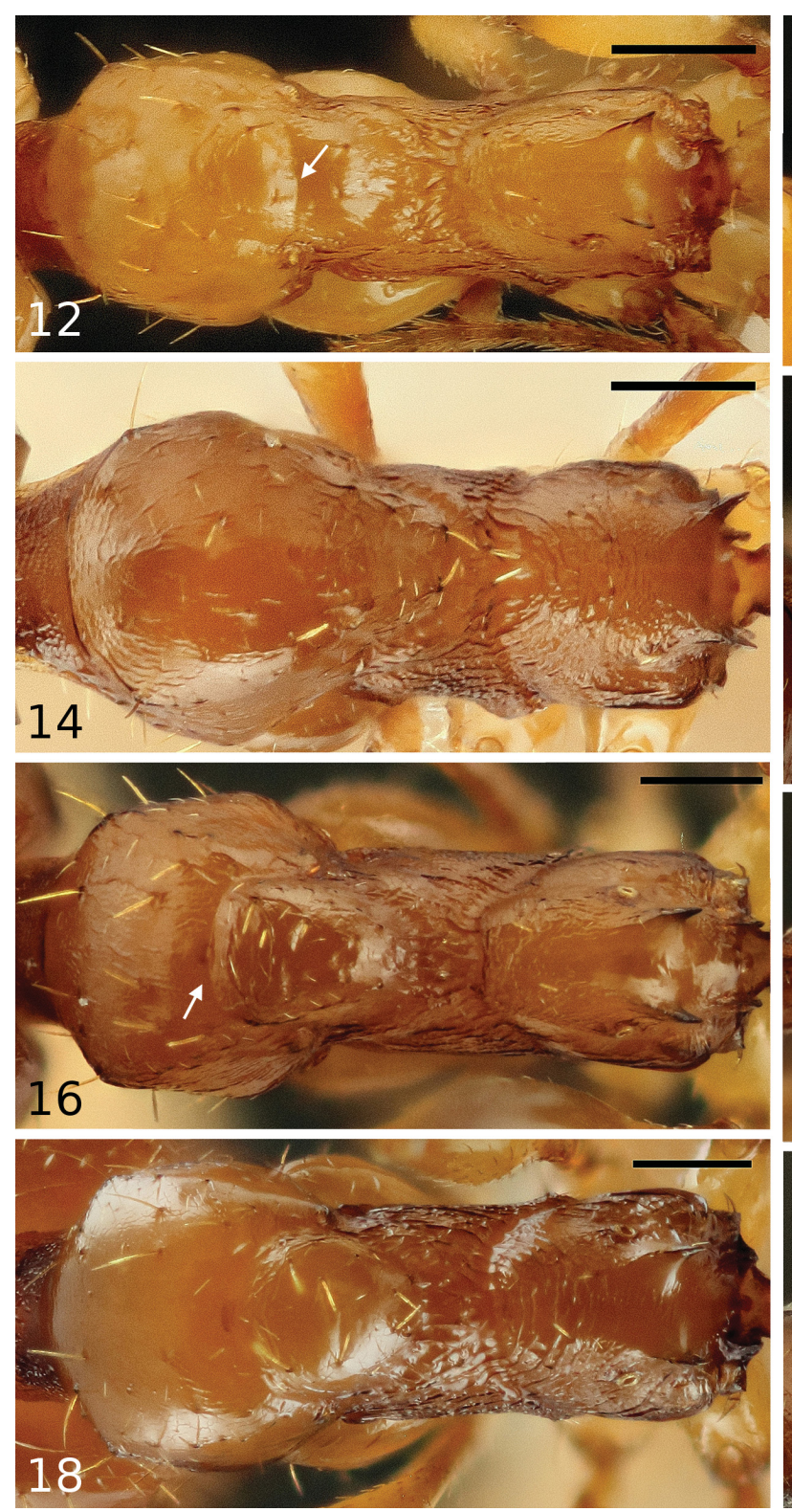

Comparative diagnosis. Worker. Yellow color of the body and appendages and the darker first gastral tergite allow to distinguish immediately A. fiorii stat. nov. from the vast majority of other sympatric Aphaenogaster species (with the exception of recently emerged workers whose pigmentation is yellowish in many other species). Among the sympatric species, only in A. splendida fully formed workers can appear similarly colored at first sight, but their mesosoma is much more elongated. Lightly colored young workers of other species or specimens with poorly preserved color can all be excluded by examining the mesosoma in lateral view (Figs 12-19): A. fiorii stat. nov. lacks the typical very marked metanotal groove of $A$. subterranea s. 1., the promesonotal suture is significantly less marked than in $A$. trinacriae sp. nov., and the mesonotum less rounded and convex than in $A$. sicula or $A$. trinacriae sp.
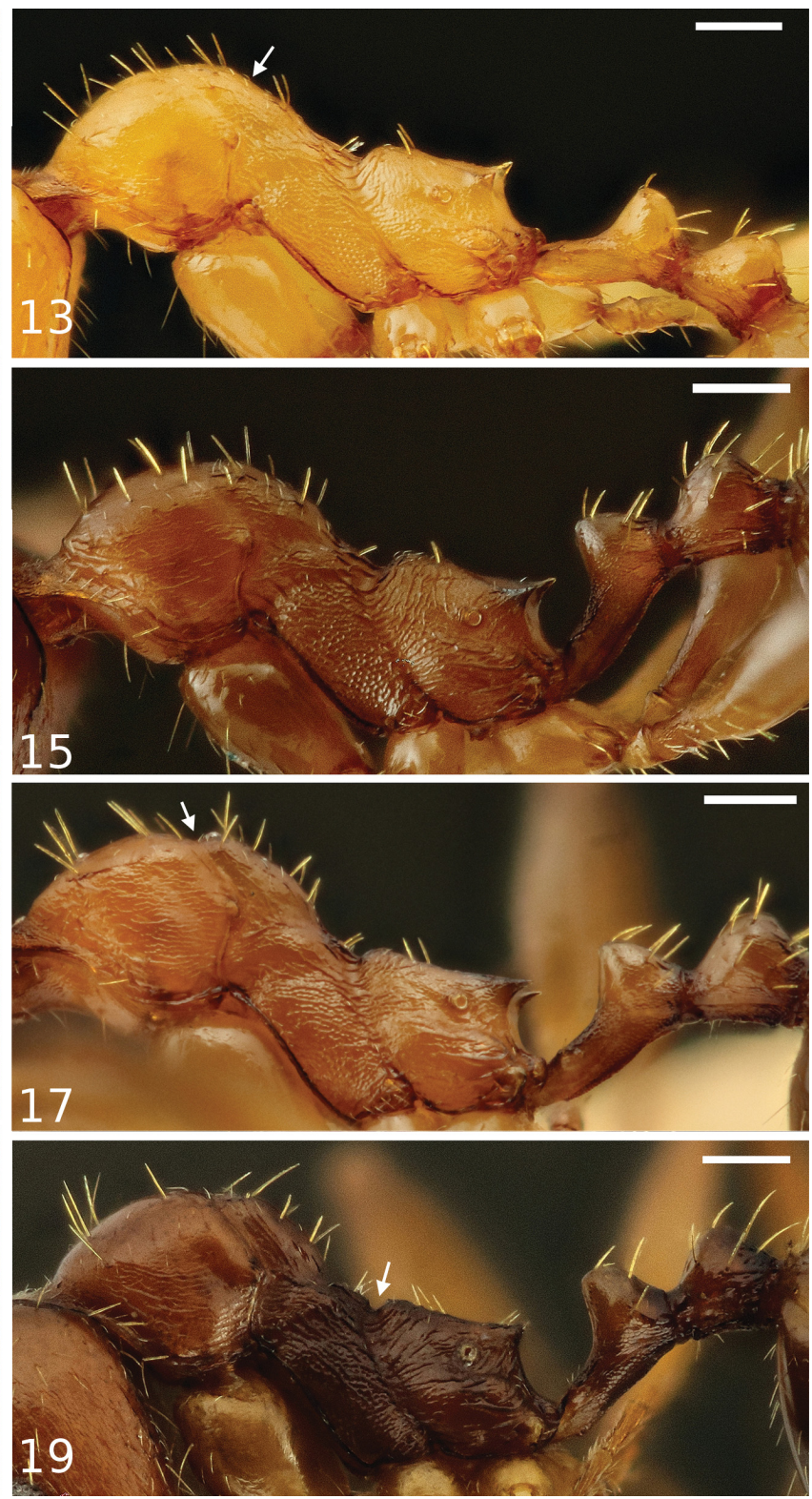

Figs 12-19. Workers mesosomata in dorsal and lateral view, which allows the observation of several diagnostic features of each species (some are highlighted by arrows). Scale bar: $0.50 \mathrm{~mm} .12,13$ - Aphaenogaster fiorii Emery, 1915, stat. nov., non-type worker from Malta; arrows pointing at the peculiar shape of the mesonotum. 14, 15 - A. sicula Emery, 1908, non-type worker from M. Pellegrino (PA), Sicily, Italy (type locality). 16, 17 - A. trinacriae sp. nov., non-type worker from Bosco della Ficuzza (PA), Sicily, Italy; arrows pointing at the characteristic promesonotal suture. 18-19-Aphaenogaster subterranea ichnusa Santschi, 1925: 18 - non-type worker from M. Petroso (PA), Sicily, Italy; 19 - non-type worker from Bosco della Ficuzza (PA), Sicily, Italy; arrow pointing at the characteristic profile corresponding to the marked metanotal groove. Photos by Enrico Schifani. 
nov. Among North African species, none shares the unique mesonotal shape or color pattern of $A$. fiorii. In addition, $A$. croce a crocea, A. crocea croceoides Forel, 1890, A crocea splendidoides Forel, 1890, and A. strioloides Forel, 1890 are considerably more sculptured.

Male. The male of $A$. fiorii stat. nov. has a yellowish-brown color (except the head) not to be confused with any other sympatric species if color is well preserved. In addition, only some Aphaenogaster males present a mesosoma with an anterior gibbous part and a comparatively flat posterior part like A. fiorii stat. nov. Among the sympatric species that do so, $A$. splendida can be easily distinguished at the very first sight by different shape of the metathorax, forming a decisively slenderer area before the propodeum in lateral view (see EMERY 1908, 1916). The male of $A$. sardoa Mayr, 1853 (see SANTSCHI 1911) is larger, darker, with a visibly less gibbous anterior part and much more abundant erect setae on the body. Aphaenogaster trinacriae sp. nov. and $A$. sicula present the most similar males, but besides being darker, they do not possess the two tubercles on the propodeum as pronounced and with the same shape. In the case of $A$. sicula the metathorax also forms a slenderer area before the propodeum, and A. trinacriae is distinguished by the well-developed enlarged flat areas on the sides of the propodeum (better observed in dorsal view). The shape of the mesosoma also distinctively separates $A$. fiorii stat. nov. from the somewhat similar Maghrebian species: $A$. crocea (see Cagniant 1966), A. faureli Cagniant, 1969 (see Cagniant 1969), A. mauritanica Dalla Torre, 1893 (see SANTSCHI 1932, Cagniant 1987), A. nadigi Santschi, 1923 (see Cagniant 1987), A. strioloides Forel, 1890 (see Santschi 1932), A. theryi Santschi, 1923 (see CAGNiant 1986, 1996).

Queen. As for the other castes, the color pattern of the yellowish queen of $A$. fiorii stat. nov. is unique among the other sympatric Aphaenogaster (even A. splendida is more reddish and also bears a well-defined transverse black stripe on the gaster). The mesosoma shape is different from most species, and only shares a significant similarity to $A$. trinacriae sp. nov., A. sicula and $A$. subterranea s. 1. All of them differ in their color as well as spines shape and length: in A. fiorii stat. nov. the spines are both long and thick. Finally, regarding the Maghrebian Aphaenogaster fauna, the scarcity of information in the literature does not allow a proper comparison with their queens.

Distribution and biogeographical remarks (Fig. 44). Aphaenogaster fiorii stat. nov. is present both in Sicily (from where it was originally described) and the Maltese islands (at least Malta and Gozo). Its presence in the Maltese islands was unknown until now due to misidentification as $A$. sicula by Baroni Urbani (1968) and Schembri \& Collingwood (1981). When BARONI URBANI (1968) affirmed that workers of $A$. crocea sicula from Malta were more monomorphic than the ones of the same species from Sicily, he was comparing misidentified workers of $A$. fiorii stat. nov. from Malta to misidentified workers of $A$. subterranea ichnusa Santschi, 1925 from Sicily (material examined by us, published in BARONI URBANI 1964 - the presence of A. subterranea ichnusa in Sicily is illustrated in Schifani \& Alicata 2018). While in Sicily A. fiorii stat. nov. appears to be distinctively rare, in Malta and Gozo it seems much more common (see also under Ecology). This could be partially explained by the reduced competition due to the reduced richness of the local ant fauna in the Maltese islands, including the Aphaenogaster fauna, which is only represented by $A$. splendida and a few species of the $A$. testaceopilosa species group there. Conversely, in Sicily A. trinacriae sp. nov., A. sicula, A. subterranea s. 1. and perhaps even A. pallida (Nylander, 1849) may represent more pressuring competitors. The SiculoMaltese chorology is known for many other taxa: Sicily and the Maltese islands were connected by a land bridge at least during the last glacial maximum in correspondence with the Hyblaean Plateau in South-Eastern Sicily (SHACKLETON et al. 1984). To this regard, it is to be noted that $A$. fiorii stat. nov. is seemingly more common in Eastern Sicily than in Western Sicily. Finally, A. fiorii stat. nov. was once recorded from Sardinia (Iglesias) by GRANDI (1935). Unfortunately, we did not manage to examine any voucher specimen in Grandi's collection to verify this record. Considering the taxonomic confusion which has affected the identity of this taxon until now, we consider Grandi's record unlikely to truly refer to $A$. fiorii stat. nov. and instead possibly related to a misidentification of $A$. subterranea ichnusa.

Ecology. In Malta the species has been frequently collected in thermophilous oak forest, but it has also been found in open areas such as a meadow on a clay soil (the usual habitat of $A$. sicula in Sicily), a very small coastal area with Limonium melitense surrounded by a road and a touristic facility, and within an area with synanthropic vegetation near crops. Moreover, it was also collected in a Mediterranean maquis. BARONI URBANI (1968, sub A. crocea sicula) found it in areas with a relatively large percentage of organic matter, such as anthropogenic areas characterized by trees, shrubs or herbaceous cover. In Sicily, it was found in oak forests and even indoors in a country house, always at higher altitudes than in the Maltese islands. Aphaenogaster fiorii stat. nov. seems to represent the most ecologically varied of the three species here treated in terms of habitat preferences. It is collected between $5 \mathrm{~m}$ and $1,000 \mathrm{~m}$.

Conservation. Our data suggest that a large part of the existing global population of this species is concentrated in the relatively small islands of Gozo and Malta, where it is widely distributed. While habitat transformation in these islands probably does not pose a huge risk (see under Ecology), potential future arrivals and outbreaks of dominant invasive ant species may be a serious threat for insular populations, as for example reported in the case of A. hesperia Santschi, 1911 in Tenerife (BARQuín 1981). To this regard, exotic ant species new to the Maltese islands unfortunately continue to be found (Gómez 2017, SALATA \& Borowiec 2018b).

Biology. Monogynous (no more than one queen per colony detected in the wild).

Phenology. In captive colonies, sexuals began to leave the nest from the second week of July to the first week of August, but no attempt to form an actual nuptial flight was detected (Alicata 1999). In the wild it can be speculated that nuptial flights may start with the first relevant rains at the end of summer. 


\section{Aphaenogaster sicula Emery, 1908}

Published records (excluding bibliographic checklists). As Aphaenogaster subterranea var. subterraneo-splendida in EMERY \& FOREL (1879) (type material - examined, see EMERY 1908) and as A. crocea sicula in EMERY (1908) (type material - examined) and KuTTER (1927) (material examined).

Material under the name A. crocea sicula in BARONI URBANI (1964) belongs to A. subterranea ichnusa (material examined), those in BARONI URBANi (1968) (material examined) and as $A$. sicula in SCHEMBri \& COLLINGWOOD (1981) (material examined) belong to $A$. fiorii stat. nov., those in Scupola (2009) (material examined) and Li Vigni (2014) (pictures examined) belong to $A$. trinacriae sp. nov.

Material published in Petrov (2000) could not be examined, but was most likely misidentified (KARAMAN 2011).

Type material examined. Lестотуре (here designated): $1 \varnothing$ (top specimen of three $\varnothing \varnothing$ on one pin), 8.XII.1877 / Mt. Pellegrino / $\not / /$ A. crocea / sicula Emery (handwritten) // Coll. C. Emery / Museo Genova // ANTWEB/ CASENT0904177 // LECTOTYPUS * / des. Alicata \& Schifani 2018 // Aphaenogaster sicula det. Alicata \& Schifani 2018 [M. Pellegrino (PA), Sicily, MSNG]. Paralectotypes: $2 \varnothing \varnothing$, same as lectotype on the same pin as the lectotype, plus // PARALECTOTYPUS // . 1 , A. crocea / sicula Emery // 8.XII.1877 / Mt. Pellegrino / \& // Coll. C. Emery / Museo Genova // PARALECTOTYPUS / des. Alicata \& Schifani 2018 // Aphaenogaster sicula det. Alicata \& Schifani 2018 [M. Pellegrino (PA), Sicily, MSNG]. 3 $\not \supset$, A. crocea sicula Emery // 8.XII.1877 / Mt. Pellegrino / $\not / /$ Coll. A. Forel // PARALECTOTYPUS / des. Alicata \& Schifani 2018 // Aphaenogaster sicula det. Alicata \& Schifani 2018 [M. Pellegrino (PA), Sicily, MHNG].

Additional material examined. ITALY: SicıLy: Segesta (AG), Sicily, Italy, 1927, leg. H. Kutter (KuTtER 1927) (MZLS); Pendici di M. Altesina,

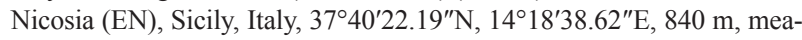
dow, 30.viii.1993, leg. A. Alicata (AACI); Colle Vampolieri, Acicatena (CT), Sicily, Italy, 37³4'21.1"N, 1509'19.4"E, 140 m, 11.xi.1993, leg. A. Alicata (AACI, MSNM); Lago Arancio, S. Margherita Belice (AG), Sicily, Italy, $37^{\circ} 38^{\prime} 43.8^{\prime \prime} \mathrm{N} 13^{\circ} 03^{\prime} 49.9^{\prime \prime} \mathrm{E}, 185 \mathrm{~m}$, meadow near the shore, 11.xii.1993, leg. A. Alicata (AACI); Misilifurmi, Sciacca (AG), Sicily, Italy, meadow, $37^{\circ} 36^{\prime} 04.4^{\prime \prime} \mathrm{N}, 13^{\circ} 02^{\prime} 44.8^{\prime \prime} \mathrm{E}, 80 \mathrm{~m}, 11 . x i i .1993$, leg. A. Alicata (AACI); Ficuzza (PA), Sicily, Italy, 3753'6.23"N, 1322'41.29"E, 650 m, meadow, 18.ii.1994, leg. A. Alicata (AACI); Baida, Scopello (TP), Sicily, Italy, $38^{\circ} 02^{\prime} 55.3^{\prime \prime} \mathrm{N}, 12^{\circ} 47^{\prime} 46.4^{\prime \prime} \mathrm{E}, 390 \mathrm{~m}$, meadow, 1.iii.1994, leg. A. Alicata (AACI); C.da Catuffo, M. Sparagio, Custonaci (TP), Sicily, Italy, $38^{\circ} 02^{\prime} 33.2^{\prime \prime} \mathrm{N}, 12^{\circ} 45^{\prime} 12.9^{\prime \prime} \mathrm{E}, 340 \mathrm{~m}$, meadow, 02.iii.1994, leg. A. Alicata (AACI); P.zo Giacolamaro, M. Sparagio, Custonaci (TP), Sicily, Italy, 38 $3^{\prime} 18.70^{\prime \prime} \mathrm{N}, 12^{\circ} 44^{\prime 2} 25.08^{\prime \prime} \mathrm{E}, 660 \mathrm{~m}$, meadow, 02.iii.1994, leg. A. Alicata (AACI); SS118 Corleone-Marineo km 26 (PA), Sicily, Italy, 3751'08.4”N, $13^{\circ} 18^{\prime} 50.7^{\prime \prime} \mathrm{E}, 490 \mathrm{~m}$, meadow, 19.ii.1994, leg. A. Alicata (AACI); Gualtieri Sicaminò (ME), Sicily, Italy, 38 $9^{\circ} 27.26^{\prime \prime} \mathrm{N}, 15^{\circ} 19^{\prime} 27.83^{\prime \prime} \mathrm{E}, 285$ m, meadow, 24.xi.1994, leg. A. Alicata (AACI); Lago di Piana, Piana

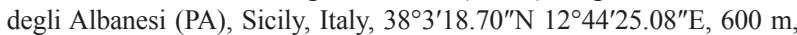
meadow near the shores, 2.iii1994, leg. A. Alicata (AACI); Pendici di M.

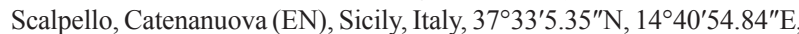
840 m, meadow, 31.iii.1999, leg. A. Alicata (AACI); Monte Pellegrino (PA), Sicily, Italy, $38^{\circ} 10^{\prime} 22.4^{\prime \prime} \mathrm{N}, 13^{\circ} 21^{\prime} 03.5^{\prime \prime} \mathrm{E}, 395 \mathrm{~m}$, Pinus reforestation, 12.iv.2016, leg. E. Schifani (ESPI); Gole del Drago (PA), Sicily, Italy, $37^{\circ} 51^{\prime} 57.1^{\prime \prime} \mathrm{N}, 13^{\circ} 18^{\prime} 03.1^{\prime \prime} \mathrm{E}, 470 \mathrm{~m}$, meadow near a degraded low Mediterranean maquis, 24.iv.2016, leg. E. Schifani (ESPI); Erice (TP), Sicily, Italy, $38^{\circ} 02^{\prime} 24.8^{\prime \prime} \mathrm{N}, 12^{\circ} 35^{\prime} 09.2^{\prime \prime} \mathrm{E}, 700 \mathrm{~m}$, meadow surrounded by Quercus ilex forest and Pinus reforestation, 04.xi.2016, leg. E. Schifani (ESPI); Lago di Prizzi (PA), Sicily, Italy, 3744'02.7"N, 13²4'28.2"E, $650 \mathrm{~m}$, meadow, 22.v.2016, leg. E. Schifani (ESPI); Grotta di S. Teodoro (ME), Sicily, Italy, 38 $03^{\prime} 00.1^{\prime \prime} \mathrm{N}, 14^{\circ} 35^{\prime} 29.8^{\prime \prime} \mathrm{E}, 135 \mathrm{~m}$, olive crops, xii.2017, leg. E. Genduso (ESPI). Italian Peninsula: Platì (RC), Italy, $38^{\circ} 13^{\prime} 05.7^{\prime \prime} \mathrm{N}, 16^{\circ} 02^{\prime} 54.5^{\prime \prime} \mathrm{E}, 280 \mathrm{~m}$, meadow, 16.xi.1993, leg. A. Alicata (AACI, MSNM); Africo Nuovo (RC), Italy, 38 ${ }^{\circ}{ }^{\prime} 52.42^{\prime \prime} \mathrm{N}, 16^{\circ} 8^{\prime} 13.52^{\prime \prime} \mathrm{E}$, 20 m, meadow, 17.xi.1993, leg. A. Alicata (AACI); F.mara S. Venere, Samo (RC), Italy, 38 $4^{\prime} 12.57^{\prime \prime} \mathrm{N}, 16^{\circ} 4^{\prime} 42.10^{\prime \prime} \mathrm{E}, 80 \mathrm{~m}$, meadow, 14.iv.1997, leg. A. Alicata (AACI); P.te Torr. S. Venere, S. Luca (RC), Italy, $38^{\circ} 08^{\prime} 42.9^{\prime \prime} \mathrm{N}$, $16^{\circ} 04^{\prime} 43.8^{\prime \prime} \mathrm{E}, 80 \mathrm{~m}$, meadow, 20.xi.1993, 23.i.2003, leg. A. Alicata (AACI,

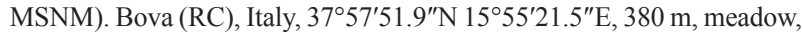
13.xi.2016, leg. E. Schifani (ESPI).
Worker redescription (Figs 5, 6, 10, 14, 15). Measurements and indices (90 individuals, 14 localities): HL: $1.05 \pm$ 0.04 (0.95-1.15); HW: $0.90 \pm 0.05$ (0.80-1.00); CI: $85.35 \pm$ 2.30 (79.54-90.69); FW: $0.77 \pm 0.04(0.67-0.85)$; SL: 1.10 \pm 0.04 (1.00-1.20); SI: $122.50 \pm 3.43$ (115.00-129.41); MW: $0.58 \pm 0.03(0.52-0.65)$; ML: $1.37 \pm 0.06(1.25$ $\pm 1.50)$. Whole body ferruginous, yellowish in freshly emerged workers, except for gaster which is dark brown. Head darker, more brownish than mesosoma and legs. Head subrectangular, lateral margins under eyes slightly rounded, posterior margin of head slightly rounded. Anterior margin of clypeus gradually convex, mandibles rounded. Antennae with twelve segments, antennal club with four segments. Promesonotal suture only slightly marked, the two forming almost continuous dorsal profile in lateral view. In lateral view dorsal profile of metanotum is rounded, dorsal profile of propodeum mostly straight, spines variable, often slightly oriented upwards. Sculpture relatively weak and shiny aspect in general. Head finely reticulated with longitudinal striae mostly limited to lateral areas under eyes, sparsely present above eyes and variably on mandibles. Mesepisternum and propodeum reticulated with fine longitudinal striae, pronotum finely imbricate, gaster smooth, petiole and postpetiole finely imbricate to reticulate. Suberect and erect setae sparse all over head, decumbent setae on mandibles, adpressed setae on scapes and adpressed to subdecumbent setae on flagellomeres. Long setae extending down from clypeus. Erect setae all over dorsal surface of mesosoma, petiole and postpetiole, and all over gaster. Mostly adpressed, partly suberect setae on legs, with sparse erect setae on coxae and femora.

Male description (Figs 22, 23, 27, 31, 32). Measurements and indices ( 5 individuals, 1 locality): HL: $0.60 \pm 0.00$; HW: $0.63 \pm 0.01$; CI: $105.00 \pm 1.83$; FW: $0.39 \pm 0.01$; SL: $0.17 \pm 0.00$; SI: $27.78 \pm 0.48$; MW: $0.69 \pm 0.01$; ML: $1.38 \pm 0.02$. Whole body brown, head and thorax sometimes slightly darker than abdomen, appendages paler than rest of body. Head subtrapezoidal, occipital margin rounded, anterior margin of clypeus presenting small concavity, eyes large and oval. Antennae with thirteen segments, antennal club with five segments. Mesosoma elongated, with anterior gibbous part formed by prothorax, mesothorax and part of metathorax, and posterior part comparatively flat formed by part of metathorax and propodeum. Promesonotal suture well marked, pronotum and mesonotum convex in lateral view, rounded on side. Metathorax arched, consisting of subvertical and subhorizontal part. Subhorizontal part, in dorsal view, becomes very narrow in proximity of subvertical part. Propodeum not much thicker than horizontal part of metathorax in lateral view. Propodeal spines are absent and only represented by two tubercles. Petiole elongated, petiolar node and postpetiolar node rounded, both dorsally present shallow longitudinal suture in center. Petiole in dorsal view presents significantly enlarged area between node and articulation with propodeum. Scape very short, covered by rare decumbent setae, decumbent to subdecumbent setae also present on head, mesosoma and legs, few erect setae on mesosoma, coxae, petiole and postpetiole and 
suberect to erect setae on gaster. Head finely reticulated, rest of body smooth and shiny.

Queen redescription (Figs 37, 38, 42). Measurements and indices ( 6 individuals, 5 localities): HL: $1.35 \pm 0.40$; HW: $1.30 \pm 0.02$; CI: $96.33 \pm 1.55$; FW: $1.11 \pm 0.02$; SL: $1.22 \pm 0.02$; SI: $93.60 \pm 1.55$; MW: $1.24 \pm 0.02$; ML: $2.30 \pm 0.04$. Whole body ferruginous, with darker areas on gaster. Head subrectangular, lateral surface below eyes rounded, posterior margin of head straight. Anterior margin of clypeus slightly convex, mandibles rounded. Antennae with twelve segments, antennal club with four segments. Pronotum rounded in dorsal view, propodeal spines horizontal and with wide base. Petiole with long peduncle and node convex on both sides, postpetiole with anterior concave side and posterior slightly convex side.
Entire head, except clypeus and occipital margin, densely covered with longitudinal striae. Long and more marked striae are subparallel to each other. Between them, less marked striae can be found often crossing each other. Mesosoma mostly shiny, with horizontal striae appearing in proximity of sutures, across propodeum and posterior faces of petiole and postpetiole. Adpressed to decumbent setae on antennae, suberect to mostly erect setae on head, dorsal part of mesosoma, of petiole and postpetiole and all over gaster. Long setae extending down from clypeus. Adpressed to decumbent setae on legs.

Systematic position. Aphaenogaster sicula first appears as Aphaenogaster subterranea var. subterraneo-splendi$d a$ in EMERY \& Forel (1879), but this is a nomen nudum (EMERY 1908). Consequently, it was then described by
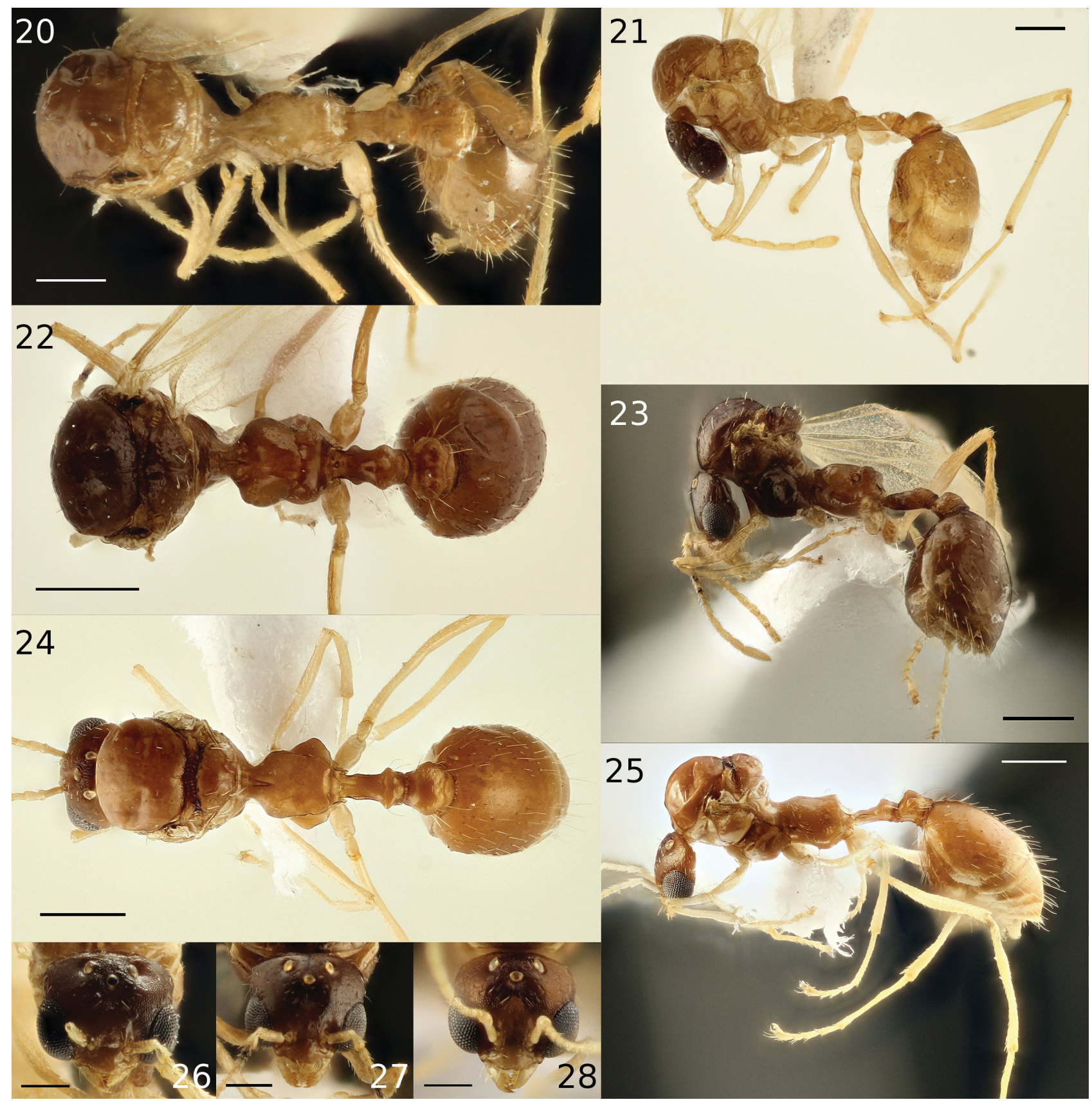

Figs 20-28. Males in dorsal, lateral (scale bar: $0.50 \mathrm{~mm}$ ) and head view (scale bar: $0.25 \mathrm{~mm}$ ). 20, 21, 26 - Aphaenogaster fiorii Emery, 1915, stat. nov., non-type male from Bosco di Aci S. Antonio, Sicily, Italy. 22, 23, 27 - A. sicula Emery, 1908, non-type male from Ficuzza, Sicily, Italy. 24, 25,28 - A. trinacriae sp. nov., paratype male AACI-ANTP003/1 from M. Sparagio, Sicily, Italy. Photos by Enrico Schifani. 
EMERY (1908) who considered it a subspecies of $A$. crocea. Aphaenogaster sicula was finally elevated to species-rank by Schembri \& Collingwood (1981) on the basis of its worker morphology. However, SCHEMBri \& Collingwood (1981) based their judgment exclusively on misidentified material of $A$. fiorii stat. nov. from Malta. Despite this fact, due to the degree of morphological differences from any other congeneric species, relevant in all three castes (see also comparative diagnosis), we surely agree to consider it a bona species.

Comparative diagnosis. Worker. The color pattern is unique among the sympatric species, having the head darker than mesosoma, both ferruginous, and the gaster very dark (somewhat resembling the Maghrebian A. strioloides). In addition, $A$. sicula presents a very reduced promesonotal suture (especially different in comparison to $A$. trinacriae sp. nov.) with a more convex mesonotum than $A$. fiorii stat. nov., while still lacking the metanotal groove marked like in $A$. subterranea s. 1. in lateral view (Figs 12-19). Moreover, A. sicula is less sculptured than most similar species (except for example the very different A. crocea lenis Santschi, 1911) and its head appears shiny if compared to that of $A$. trinacriae sp. nov. It is also a relatively small species.

Male. Only some of the Aphaenogaster males present a mesosoma with an anterior gibbous part and a comparatively flat posterior part like $A$. sicula. Among the sympatric species that do so, $A$. splendida can be easily distinguished by different shape of the metathorax, forming a decisively slenderer area in front of the propodeum in lateral view (see EMERY 1908, 1916). Aphaenogaster sardoa male (SANTSCHI 1911) is larger, its metathorax does not form slenderer part in front of the propodeum, it possesses a visibly less gibbous anterior part and more abundant erect setae on the body.
29

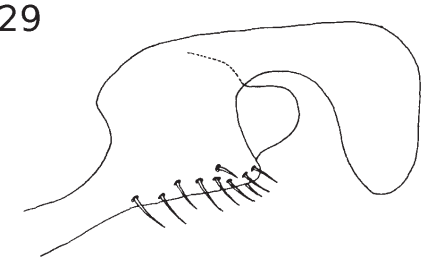

31

\section{3}

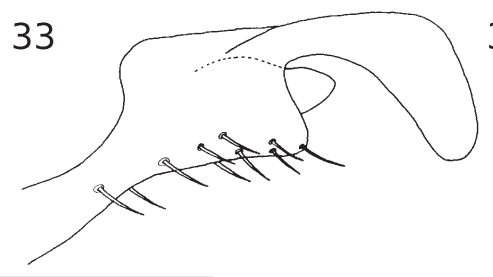

$0.1 \mathrm{~mm}$

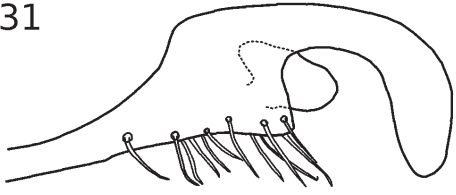

30

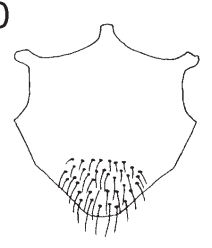

32

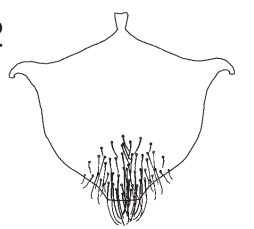

34

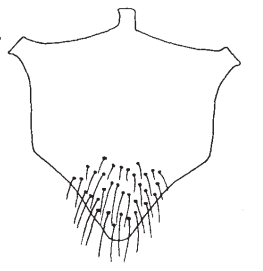
of the subgenita left) and of the subgenital plate (right). 29, 30 - Aphaenogaster fiorii Emery, 1915, stat. nov. 31, 32 - A. sicula Emery, 1908. 33, 34 - A. trinacriae sp. nov. Drawings by Antonio Alicata.
Aphaenogaster fiorii stat. nov. and A. trinacriae sp. nov. are the most similar, but do not possess the aforementioned slenderer part in front of the propodeum in the flatter part of the mesosoma. In addition, A. fiorii stat. nov. is much lighter in color and presents more developed and differently shaped tubercles on the propodeum, while $A$. trinacriae sp. nov. is distinguished by the well-developed enlarged flat areas on the sides of the propodeum (better observed in dorsal view). The shape of the mesosoma also distinctively separates $A$. sicula from the somewhat similar Maghrebian species: $A$. crocea (see Cagniant 1966), A. faureli (see Cagniant 1969), A. mauritanica (see SANTSCHI 1932, CAGniant 1987), A. nadigi (see CAGNiant 1987), A. strioloides (see SANTSCHI 1932), and $A$. theryi (see CAGNiant 1986, 1996).

Queen. Among sympatric species the mesosoma shape in $A$. sicula is only similar to that of $A$. fiorii stat. nov., $A$. trinacriae sp. nov. and $A$. subterranea s. 1. However, $A$. fiorii stat. nov. is chromatically very different, and $A$. subterranea s. 1. is also often darker. Moreover, $A$. sicula is unique for its short and thick spines. The scarcity of available information does not allow a proper comparison with the Maghrebian forms.

Distribution and biogeographical remarks (Fig. 45). Aphaenogaster sicula seems to inhabit the whole Sicilian territory where the required ecological conditions are met and is also present in a small area in the southern part of Calabria. Further investigation is probably needed to establish its northernmost range limit. Land connections between Calabria and Sicily occurred relatively frequently during the later stages of the Pleistocene (Bonfiglio et al. 2002), and a Siculo-South Calabrian chorotype was established for the Italian fauna (Stoch \& Vigna Taglianti 2006). Dispersion of $A$. sicula most likely occurred from Sicily to Calabria. Its alleged presence in the Maltese islands was based exclusively on misidentified specimens of $A$. fiorii stat. nov. as already mentioned. Finally, BARONI URBANI (1971) interpreted BERNARD's (1958) record of $A$. crocea for Lampedusa as A. crocea sicula but MeI (1995) considered the original record by Bernard erroneous and based on a misidentification of $A$. sardoa. More recent collecting efforts only reinforce Mei's hypothesis (ES, unpublished data; A. Scupola, unpublished data). A particularly aberrant record was published by Petrov (2000) for Montenegro (without any more precise locality), but it was most likely a result of misidentification (KARAMAN 2011).

Ecology. Aphaenogaster sicula inhabits clay soils, living in meadows most of the times, but also in garrigues or degraded Mediterranean maquis, and can also be found in Pinus afforestations at low altitudes. Nonetheless, it is generally associated with open habitats. It is collected between $35 \mathrm{~m}$ and $840 \mathrm{~m}$.

Conservation. Viable habitats for A. sicula seem to be abundant in its distribution range. Unless a massive change in land usage takes place, the species should not face particular threats. In addition, the data here presented (Fig. 45) may represent a significant underestimation of its distribution in Sicily.

Biology. Monogynous (no more than one queen per colony detected in the wild). 
Phenology. In captive colonies, sexuals began to leave the nest from the second week of July to the first week of August, but no attempt to form an actual nuptial flight was detected. In the wild it can be speculated that nuptial flights may start with the first relevant rains at the end of summer.

\section{Aphaenogaster trinacriae sp. nov.}

Published records (excluding catalogues). As Aphaenogaster sp. n. in Alicata (1999) (type material and other examined material).

Misidentified as A. sicula in Scupola (2009) (material examined), LI VIGNI (2014) (pictures examined), LEBAS et al. (2016) (pictures examined) and as A. splendida in Scupola (2017) (material examined).

Type material. Holotype: $1 \curlyvee$, Aphaenogaster trinacriae Alicata \& Schifani // Italy - Sicilia - Custonaci TP / M. Sparagio, P.zzo Giacolamaro / 38॰3'56.42”N 1246’43.14”E 700 m / Alicata leg. - 2.III.1994 / Q. ilex forest - AACI-ANTP001/1 // HOLOTYPUS / des. Alicata \& Schifani // A. trinacriae det. Alicata \& Schifani 2018 (MSNG). PARATYPES: ITALY: SiCILY: $2 \not \varnothing$, , same as holotype except AACI-ANTP001/3 // PARATYPUS / des. Alicata \& Schifani (MSNG); $3 \not \varnothing$, same as holotype except 22.XI.1996 / AACI-ANTP002/2 PARATYPUS / des. Alicata \& Schifani (MSNG); 1 , same as holotype except 8.VII.1997 / from rearing - AACI-ANTP003/1 PARATYPUS / des. Alicata \& Schifani (in photo, MSNG); 1 , same as holotype except 8.VII.1997 / from rearing - AACI-ANTP003/2 PARATYPUS / des. Alicata \& Schifani (MSNG); 19 , same as holotype except AACI-ANTP001/2 // PARATYPUS / des. Alicata \& Schifani (MSNG); 1 \% , same as holotype except 22.XI.1996 / AACI-ANTP002/1 PARATYPUS / des. Alicata \& Schifani (MSNG); $4 \not \varnothing$, , Erice 10.xii.1993 / leg. Alicata // PARATYPUS / des. Alicata \& Schifani // A. trinacriae det. Alicata \& Schifani 2018 (MSNM); $8 \varnothing \varnothing$ and 1 ○, Italy - Sicilia - Erice TP / M. Erice m 600 / mixed forest / 10.XII.1993 leg. Alicata // PARATYPUS / des. Alicata \& Schifani // A. trinacriae det. Alicata \& Schifani 2018 (AACI); $2 \hat{\jmath}$, Italy - Sicilia - Erice TP / M. Erice m 600 / from rearing / 14.VII.1997 leg. Alicata // PARATYPUS / des. Alicata \& Schifani // A. trinacriae det. Alicata \& Schifani 2018 (AACI). Additional material examined. ITALY: SiCILY: Monte S. Caterina vers. W, Favignana (TP), Sicily, Italy, 3756 $20^{\prime \prime} \mathrm{N}, 12^{\circ} 18^{\prime} 29^{\prime \prime} \mathrm{E}, 110 \mathrm{~m}$, Mediterranean maquis, 2.v.1991, leg. R. Poggi (MSNG); M. Erice, Erice (TP), Sicily, Italy, $38^{\circ} 2^{\prime} 14.52^{\prime \prime} \mathrm{N}, 12^{\circ} 35^{\prime} 42.99^{\prime \prime} \mathrm{E}$, from 450 to $600 \mathrm{~m}$, mixed forest and Pinus reforestation, 10.xii.1993, 21.xi.1996, 6.xii.1996, leg. A. Alicata (AACI, MSNM); M. Altesina, Nicosia (EN), Sicily, Italy, $37^{\circ} 40^{\prime} 18.49^{\prime \prime} \mathrm{N}, 14^{\circ} 18^{\prime} 30.34^{\prime \prime} \mathrm{E}, 915 \mathrm{~m}$, Quercus ilex forest, 30.viii.1994, leg. A. Alicata (AACI); Bosco di Gibilmanna, Gibilmanna (PA), Sicily, Italy, deciduous forest of the Quercus pubescens group, 28.v.1996, leg. A. Alicata (AACI); V.ne Fanuso, Bosco della Ficuzza (PA), Sicily, Italy, mixed forest, 24.v.1996, 18.iii.1997, 29.iii.1997, leg. A. Alicata (AACI); C.da Pintorna, Geraci Siculo (PA), Sicily, Italy, Quercus suber forest, 30.v.1996, leg. A. Alicata (AACI); C.da Albinelli, Sortino (SR), Sicily, Italy, $37^{\circ} 12^{\prime} 16.99^{\prime \prime} \mathrm{N}, 15^{\circ} 4^{\prime} 51.15^{\prime \prime} \mathrm{E}, 365 \mathrm{~m}$, Quercus suber forest, 3.x.1996, leg. A. Alicata (AACI); Baida, Scopello (TP), Sicily, Italy, $38^{\circ}$ $2^{\prime} 57.11^{\prime \prime} \mathrm{N}, 12^{\circ} 47^{\prime} 44.97^{\prime \prime} \mathrm{E}, 480 \mathrm{~m}$, Mediterranean maquis, 20.xi.1996, leg. A. Alicata (AACI); Bosco Scorace, Castellammare del Golfo (TP), Sicily, Italy, Quercus ilex forest, 15.xii.1997, leg. A. Alicata (AACI); Pizzo Giacolamaro, M. Sparagio, Custonaci (TP), Sicily, Italy, 38 $3^{\prime} 56.42^{\prime \prime} \mathrm{N}$, $12^{\circ} 46^{\prime} 43.14^{\prime \prime} \mathrm{E}, 685 \mathrm{~m}$, Quercus ilex forest, 21.xi.1997, leg. A. Alicata (AACI); Monte Sparagio, Custonaci (TP), Sicily, Italy, 38³'56.42”N $12^{\circ} 46^{\prime} 43.14^{\prime \prime} \mathrm{E}, 550 \mathrm{~m}$, Quercus ilex forest, 21.xi.1997, leg. A. Alicata (AACI); Pizzo Niviere, M. Inici, Castellammare del Golfo (TP), Sicily, Italy, $38^{\circ} 0^{\prime} 22.88^{\prime \prime} \mathrm{N}, 12^{\circ} 51^{\prime} 13.22^{\prime \prime} \mathrm{E}, 1,000 \mathrm{~m}$, Quercus ilex forest, 22.xi.1997, leg. A. Alicata (AACI); V.ne Schiavo, Bosco del Cappelliere (PA), deciduous forest of the Quercus pubescens group, 19.iii.1997, leg. A. Alicata (AACI); Bosco di Alcamo, Alcamo (TP), Sicily, Italy, $37^{\circ} 57^{\prime} 24.56^{\prime \prime} \mathrm{N}, 12^{\circ} 57^{\prime} 47.58^{\prime \prime} \mathrm{E}, 770 \mathrm{~m}$, mixed forest, 26.vi.1997, leg. A. Alicata (AACI); Alpe Ramosa, Bosco della Ficuzza (PA), Sicily, Italy, Quercus ilex forest, 28.vi.1997, leg. A. Alicata (AACI); Pulpito del Re, Bosco della Ficuzza (PA), Sicily, Italy, Quercus suber forest, 28.vi.1997, leg. A. Alicata (AACI); Lago Gammauta, Palazzo Adriano (PA), Sicily, Italy, 3741'5.27"N, 1320'53.66"E, $500 \mathrm{~m}$, mixed forest, 10.vii.1997, leg. A. Alicata (AACI); Santuario di Rifesi, Burgio (AG), Sicily, Italy, deciduous forest of the Quercus pubescens group, 37³6'33.96" $\mathrm{N}$, $13^{\circ} 20^{\prime} 46.08^{\prime \prime} \mathrm{E}, 775 \mathrm{~m}, 11 . v i i .1997$, leg. A. Alicata (AACI); Serra del Biondo, Burgio (AG), Sicily, Italy, 37³7'22.95"N, 13¹9'53.82"E, 1,070 m, Pinus reforestation, 11.vii.1997, leg. A. Alicata (AACI); Valle del Sosio, Palazzo Adriano (PA), Sicily, Italy, 3740'49.61"N , 13²0'48.47"E, 480 m, Quercus ilex forest, 27.vii.1997, leg. A. Alicata (AACI); C.da Sugherita, M. Sambughetti-Campanito, Nicosia (EN), Sicily, Italy, Quercus suber forest, 29.viii.1997, leg. A. Alicata (AACI); Bosco Scorace, Castellammare del Golfo (TP), Sicily, Italy, 3759'14.51"N, 1245'31.62"E, 385 m, Quercus ilex forest, 15.xii.1997, leg. A. Alicata (AACI); P.lla Manderini, Geraci Siculo (PA), Sicily, Italy, 1,260 m, deciduous forest of the Quercus pubescens group, 24.ix.1998, leg. A. Alicata (AACI); T.rre Montaspro, Isnello (PA), Sicily, Italy, $870 \mathrm{~m}$, Quercus ilex forest, 02.x.1998, leg. A. Alicata (AACI); V.ne Zucchi, Isnello (PA), Sicily, Italy, 985 m, Quercus ilex forest, 02.x.1998, leg. A. Alicata (AACI); Piano Zucchi, Isnello (PA), Sicily, Italy, 1,070 m, Quercus ilex forest, 02.x.1998, leg. A. Alicata (AACI); Vallone Moscasanti, R.N.O. Grotta

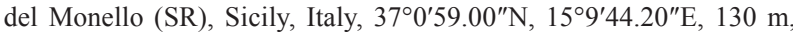
mixed forest, pitfall traps, 21.x.2004, leg. A. Alicata (AACI); Torretta Torre, Bosco della Ficuzza (PA), Sicily, x.2005, Malaise traps, leg. A. Gatto, sub A. splendida (Scupola 2017; the cited worker was not found) (MSNM); Bosco Scalia (PA), Sicily, 38 $01^{\prime} 39.9^{\prime \prime} \mathrm{N}, 13^{\circ} 12^{\prime} 46.0^{\prime \prime} \mathrm{E}, 815$ m, Quercus ilex forest, 08.iv.2016, leg. E. Schifani (ESPI); Bosco della Ficuzza (PA), Sicily, 3751'46.2”N, 132'09.2"E, 980 m, deciduous forest of the Quercus pubescens group, 23.vii.2016, leg. E. Schifani (ESPI); Bosco della Ficuzza (PA), Sicily, 3752'29.8'N, 1323'54.3"E, 855 m, Quercus suber forest, 02.xii.2016, leg. E. Schifani (ESPI); Erice

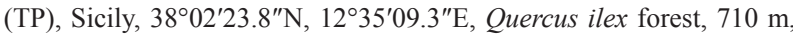
04.xi.2016, leg. E. Schifani (ESPI); Bosco del Cappelliere (PA), Sicily, $37^{\circ} 55^{\prime} 30.0^{\prime \prime} \mathrm{N}, 13^{\circ} 23^{\prime} 18.0^{\prime \prime} \mathrm{E}, 520 \mathrm{~m}, 27 . v .2017$, leg. R. Viviano (ESPI); Bosco della Ficuzza (PA), Sicily, 37 $52^{\prime} 03^{\prime \prime N}$, 13²3'44"E, 960 m, 1.viii.2017, leg. E. Nalini (ESPI, MSNM).

Worker description (Figs 7, 8, 11, 16, 17). Measurements and indices (holotype worker): HL: 1.25; HW: 1.07; CI: 85.60; FW: 0.92; SL: 1.22; SI: 114.01; MW: 0.7; ML: 1.65: Measurements and indices ( 89 individuals, 14 localities; including holotype): HL: $1.16 \pm 0.05$ (0.97-1.27); HW: $1.01 \pm$ 0.07 (0.77-1.17); CI: 87.14 \pm 2.81 (79.48-92.15); FW: 0.87 $\pm 0.06(0.70-1.00)$; SL: $1.17 \pm 0.04(1.05-1.27)$; SI: $115.59 \pm$ 5.24 (106.38-135.48); MW: $0.64 \pm 0.04$ (0.52 \pm 0.75$)$; ML: $1.52 \pm 0.08(1.27-1.70)$. Whole body ferruginous (yellowish in freshly emerged workers), except for dark gaster. Central area of frons, scapi and femora are in some cases also darker than rest of head. Head subrectangular, lateral margins under eyes slightly rounded, posterior margin of head straight. Anterior margin of clypeus gradually convex, mandibles rounded. Antennae with twelve segments, antennal club with four segments. Promesonotal suture well-marked, creating clear discontinuity of dorsal profile in lateral view. In lateral view, dorsal profile of metanotum is rounded, dorsal profile of propodeum mostly straight, spines are variable in size and orientation, but are often horizontal. Sculpture relatively well developed in general. Head reticulated, with longitudinal striae almost reaching occiput, strongly developed especially under and around eyes, and present on mandibles. Mesepisternum and propodeum reticulated with fine longitudinal striae, pronotum finely imbricate, gaster smooth, petiole and postpetiole finely imbricate to reticulate. Suberect and erect setae sparse over head, decumbent setae on mandibles, adpressed setae on scapes and adpressed to subdecumbent setae on flagellomeres. Long setae extending down from clypeus. Erect setae all over dorsal surface of mesosoma, petiole and postpetiole, and all over gaster. Mostly adpressed, partly suberect setae on legs, with sparse erect setae on coxae and femora. 
Male description (Figs 24, 25, 28, 33, 34). Measurements and indices (5 individuals, 1 locality): HL: $0.72 \pm 0.02$; HL: $0.72 \pm 0.03$; CI: $99.35 \pm 1.44$; FW: $0.48 \pm 0.01$; SL: $0.23 \pm$ 0.01 ; SI: $32.65 \pm 1.92$; MW: $0.91 \pm 0.09$; ML: $1.73 \pm 0.10$. Whole body brown, appendages paler than rest of body. Head subtrapezoidal, occipital margin rounded, anterior margin of clypeus presenting small concavity, eyes large and oval. Antennae with thirteen segments, antennal club with five segments. Mesosoma elongated, with anterior gibbous part formed by prothorax, mesothorax and part of metathorax, and posterior part comparatively flat formed by part of metathorax and propodeum. Promesonotal suture well marked, pronotum and mesonotum convex in lateral view, rounded on side. Metathorax arched, consisting of subvertical and subhorizontal part. Subhorizontal part, in dorsal view, becomes very narrow in proximity of subvertical part. Propodeum not much thicker than horizontal part of metathorax in lateral view, bearing two particularly
35

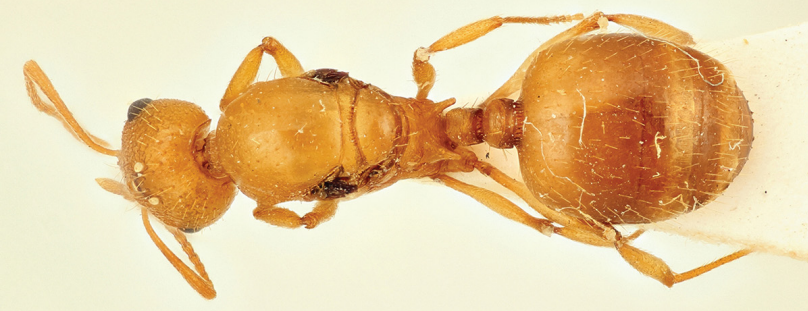

37

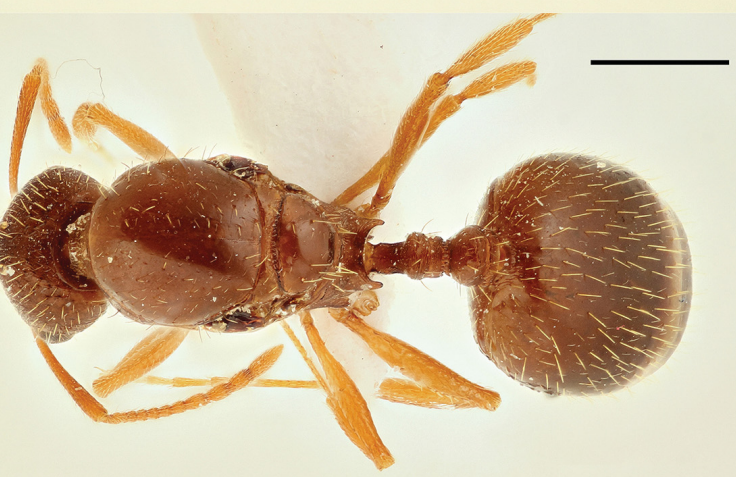

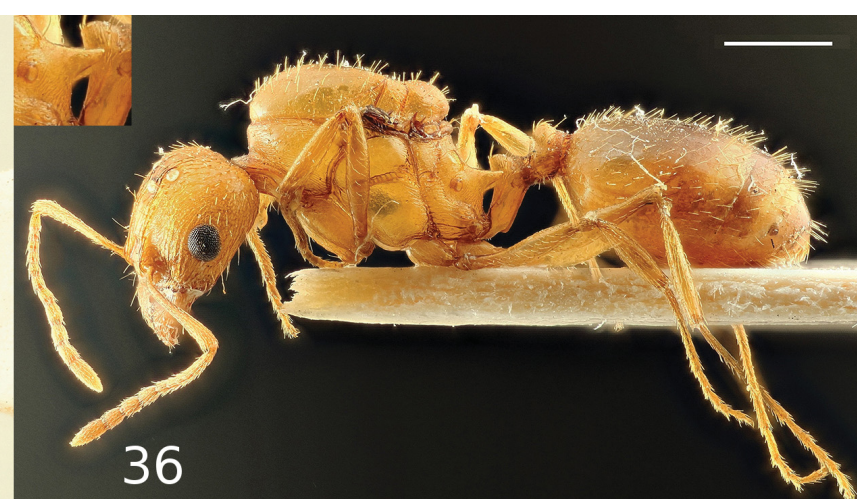

39
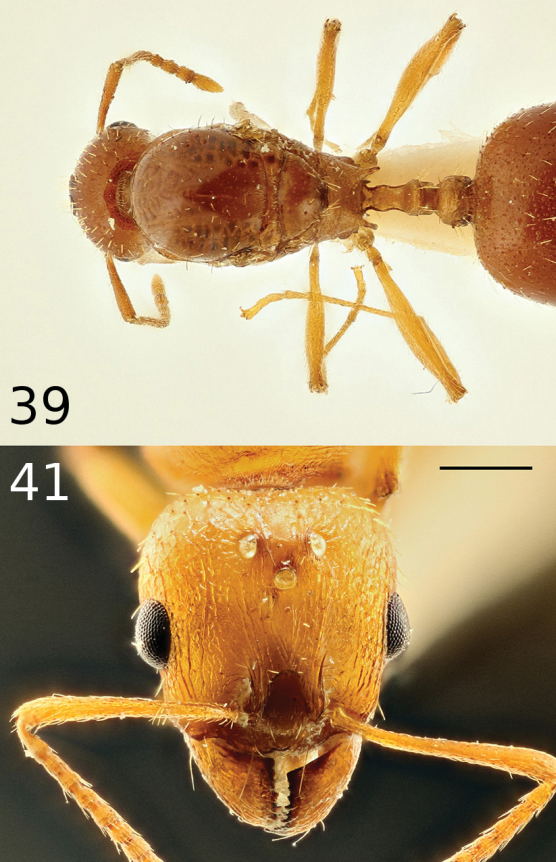

36

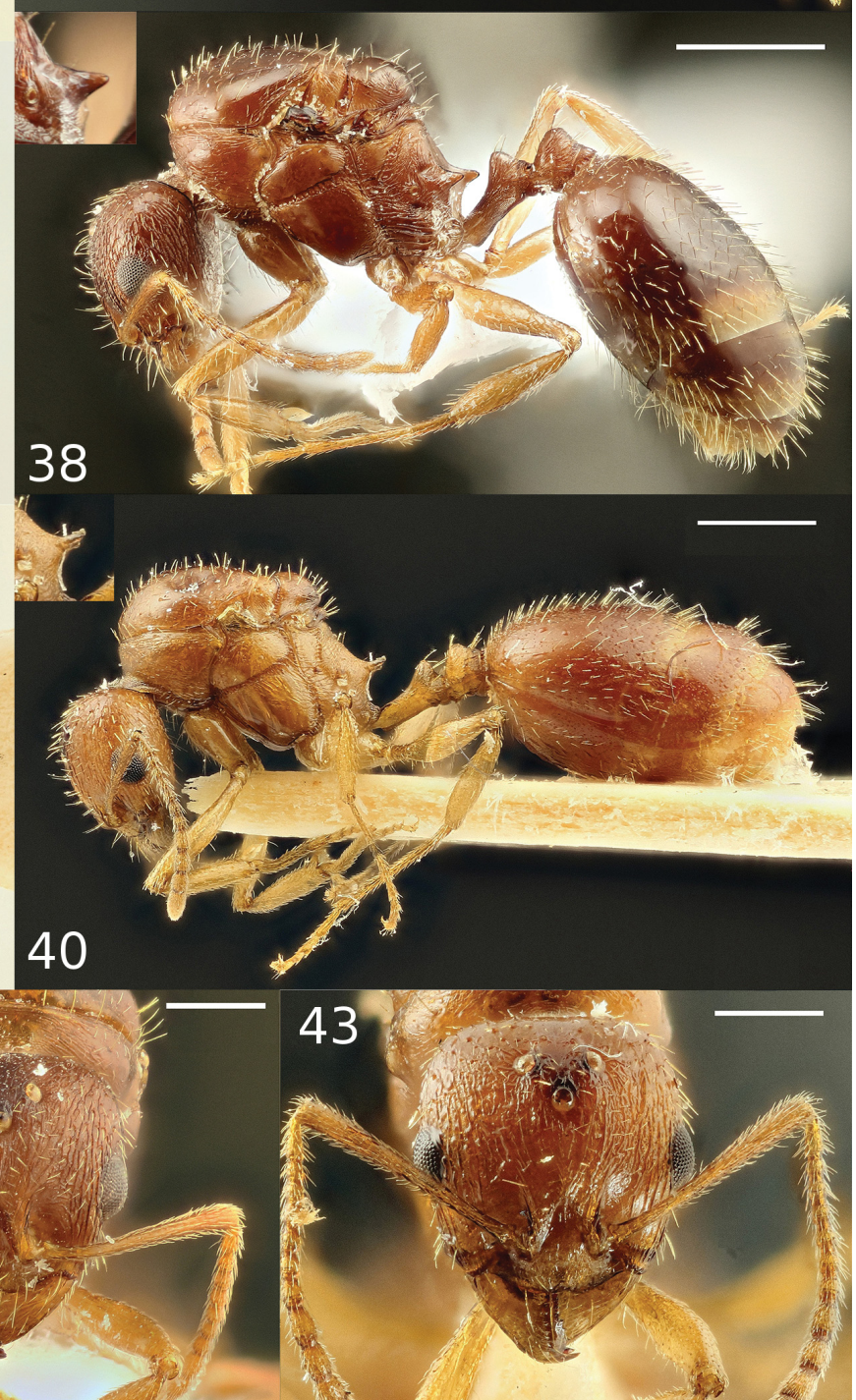

Fig 35-43. Queens in dorsal, lateral view (scale bar: $1.00 \mathrm{~mm}$ ), detail of spines in lateral view (no scale bar) and head view (scale bar: $0.50 \mathrm{~mm}$ ). 35 , 36, 41 - Aphaenogaster fiorii Emery, 1915, stat. nov., non-type queen from Bosco di Aci S. Antonio, Sicily, Italy. 37, 38, 42 - A. sicula Emery, 1908, non-type queen from Contrada Catuffo, pendici M. Sparagio, Sicily, Italy. 39, 40, 43 - A. trinacriae sp. nov., paratype queen AACI-ANTP002/1 from M. Sparagio, Sicily, Italy. Photos by Enrico Schifani. 
enlarged flat areas on its sides (better observed in dorsal view). Propodeal spines are absent and only represented by two tubercles. Petiole elongated, petiolar node and postpetiolar node rounded, both dorsally presenting shallow longitudinal suture in center. Scape very short, covered by rare decumbent setae, decumbent to subdecumbent setae also present on head, mesosoma and legs, a few erect setae on mesosoma, coxae, petiole and postpetiole, suberect to erect setae on gaster. Head finely reticulated, rest of body smooth and shiny.

Queen description (Figs 39, 40, 43). Measurements and indices (4 individuals, 3 localities): HW: $1.36 \pm 0.01$; HL: $1.29 \pm 0.02$; CI: $94.52 \pm 0.01$; FW: $1.12 \pm 0.00$; SL: $1.23 \pm 0.01$; SI: $95.18 \pm 1.03$; MW: $1.25 \pm 0.03$; ML: $2.36 \pm 0.04$. Whole body ferruginous, some lighter bands on gaster. Head subrectangular, lateral surface below eyes rounded, posterior margin of head straight. Anterior margin of clypeus slightly convex, mandibles rounded. Antennae with twelve segments, antennal club with four segments. Pronotum rounded in dorsal view, propodeal spines slightly tending upwards and slender. Petiole with long peduncle and node convex on both sides, postpetiole with anterior concave side and posterior slightly convex side. Entire head, except clypeus and occipital margin, densely covered with longitudinal striae. Long and more marked striae are subparallel to each other. Between them, less marked striae can be found often crossing each other. Mesosoma mostly shiny, with horizontal striae appearing in proximity of sutures, across propodeum and posterior faces of petiole and postpetiole. Adpressed to decumbent setae on antennae, suberect to mostly erect setae on head, dorsal part of mesosoma, of petiole and postpetiole and all over gaster. Long setae extending down from clypeus. Adpressed to decumbent setae on legs.

Comparative diagnosis. Worker. Aphaenogaster trinacriae sp. nov. is characterized by ferruginous color of the body except for the very dark gaster and potential presence of dark area on the frons. Among the sympatric species this pattern can only be confused with some individuals of $A$. subterranea ichnusa or A. sicula. Aphaenogaster subterranea ichnusa can be easily distinguished by the marked metanotal groove in lateral view, less sculptured pronotum and different shape of the mesonotum. Aphaenogaster sicula tends to have darker head compared to the thorax and it is overall much less sculptured. Moreover, it presents a very reduced promesonotal suture, which on the contrary is very well marked in A. trinacriae sp. nov. The shape of the mesonotum and its sculpture easily separate $A$. trinacriae from any other similar Maghrebian congeneric species.

Male. Only some of the Aphaenogaster males present mesosoma with an anterior gibbous part and a comparatively flat posterior part like $A$. trinacriae sp. nov. Among the sympatric species that do so, $A$. splendida can be easily distinguished by different shape of the metathorax, forming a decisively slenderer area in front of the propodeum in lateral view (see EMERY 1908; 1916). Aphaenogaster sardoa male (SANTSCH 1911) is larger, its metathorax does not form a slenderer part in front of the propodeum, it possesses a visibly less gibbous anterior part and much more abundant erect setae on the body. Aphaenogaster fiorii stat. nov. and $A$. sicula are the most similar, but do not possess the well developed enlarged flat areas on the sides of the propodeum (better observed in dorsal view). In addition, $A$. fiorii stat. nov. is much lighter and presents more developed and differently shaped tubercles on the propodeum. The shape of the mesosoma also distinctively separates $A$. trinacriae sp. nov. from the somewhat similar Maghrebian species: A. crocea (see Cagniant 1966), $A$. faureli (see CAGNIANT 1969), A. mauritanica (see SANTSCHI 1932, Cagniant 1987), A. nadigi (see Cagniant 1987), $A$. strioloides (see SANTSCHI 1932), A. theryi (see Cagniant 1986, 1996).

Queen. Among sympatric species the mesosoma shape is only similar to that of $A$. fiorii stat. nov., $A$. sicula and A. subterranea s. 1. However, A. fiorii stat. nov. is chromatically very different, and both $A$. fiorii stat. nov. and $A$. sicula possess thicker spines. Aphaenogaster subterranea s. 1. appears to be very similar but it is usually darker and possesses more rectangular head with more parallel sides in frontal view. The scarcity of available information does not allow a proper comparison with the Maghrebian forms. Etymology. Trinacria is the ancient Greek name of Sicily; noun in genitive case standing in apposition.

Distribution and biogeographical remarks (Fig. 46). Aphaenogaster trinacriae sp. nov. has the smallest distribution range of the three species, being exclusively limited to Sicily, where it is most abundant in its Western regions and completely absent in its North Eastern regions: in Etna, Nebrodi and Peloritani mountains the same habitats are occupied only by the ecologically similar $A$. subterranea ichnusa, and very rarely by $A$. fiorii stat. nov. Aphaenogaster trinacriae sp. nov. was also found in Favignana, a sedimentary island belonging to the Egadi Islands, which is about $7 \mathrm{~km}$ distant from the Western Sicilian coast and was alternately connected by land to Sicily in the past (Agnesi et al. 1993).

Ecology. This species was mostly collected in natural Quercus forest but occasionally also in some artificial Pinus forest. All sites were either fully established forest or degraded forest. Altitude between $110 \mathrm{~m}$ and 1,260 m. Aphaenogaster trinacriae sp. nov. partly shares its distribution with that of $A$. subterranea ichnusa, whose ecology requirements are seemingly vastly overlapping (SCHIFANI \& Alicata 2018), therefore competition between these two may be expected to be significant. On the contrary, A. subterranea s. str. is found at higher altitudes and/or in different habitats in Sicily (SCHIFANI \& AliCATA 2018). Aphaenogaster trinacriae was reported removing elaiosomes from seeds of Euphorbia characias (LI VIGNI 2014, $\operatorname{sub} A$. sicula).

Conservation. Aphaenogaster trinacriae sp. nov. appears to have a well-defined habitat specificity mainly linked to thermophilous broad-leaved forests. Its abundance within the relatively small distribution range must have been severely reduced due to the very important deforestation that occurred in the past (LA Mantia 2009). Many sites in which the species is found are habitat patches likely too distant from each other to allow the species dispersal 


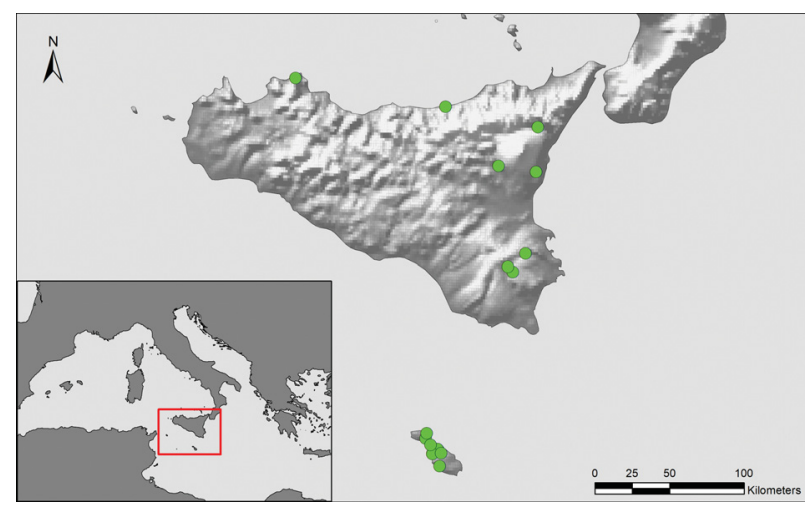

Fig 44. Distribution of Aphaenogaster fiorii Emery, 1915, stat. nov.

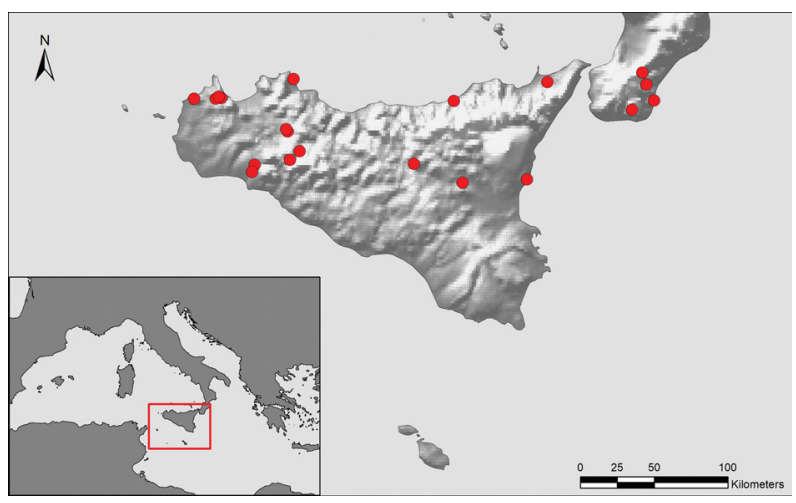

Fig 45. Distribution of Aphaenogaster sicula Emery, 1908.

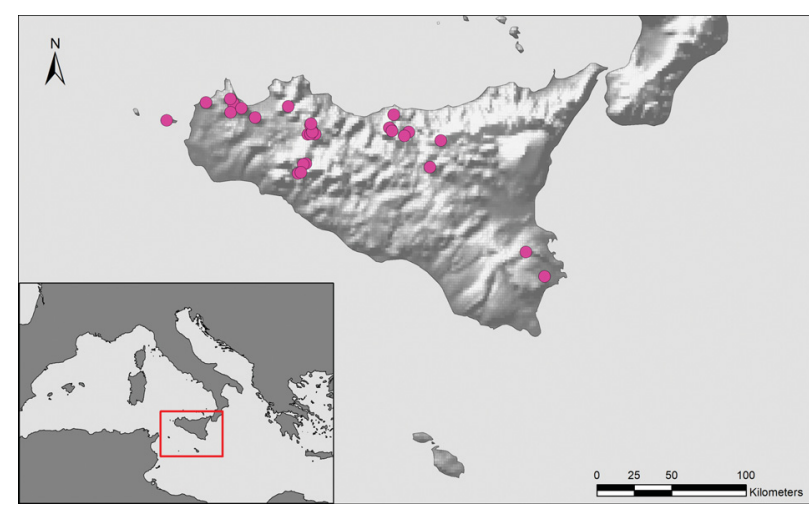

Fig 46. Distribution of Aphaenogaster trinacriae sp. nov.

from one patch to another, resulting in presumably complete isolation of these populations. Although reforestation projects have increased the forested surface in Sicily, they may have not necessarily helped the species to recover the lost habitats. Aphaenogaster trinacriae sp. nov. has never been found in Eucalyptus reforestations, and reforestation patches of other kind may sometimes be too isolated to be colonized. It would be worth investigating if the abundant presence of $A$. subterranea ichnusa in some isolated reforested areas, in which $A$. trinacriae sp. nov. is absent despite seemingly adequate ecological conditions, is due to the lower dispersal capacity of the latter or unintentional introductions of the former.

Biology. Monogynous (no more than one queen per colony detected in the wild, attempts to found colonies in captivity with multiple queens only resulted in monogynous colonies).
Phenology. Winged sexuals were collected in nests in Bosco della Ficuzza (PA) during the last week of July and in C. da Sugherita, M. Sambughetti-Campanito (EN) in August. In captive colonies, sexuals began to leave the nest from the second week of July to the first week of August, but no attempt to form an actual nuptial flight was detected (Alicata 1999). In the wild, it can be speculated that nuptial flights may start with the first relevant rains at the end of summer.

Myrmecophiles. Six individuals of Scydmaenus rufus Müller \& Kunze, 1822 (Staphylinidae, Scydmaeninae) were collected inside a nest of $A$. trinacriae sp. nov. in Bosco della Ficuzza (PA) during December. Several associations between staphylinids of the subfamily Scydmaeninae Leach, 1815 and ants are known (O'KeEFE 2000), however most of them are probably facultative (PARKER 2016).

\section{Discussion}

The position of $A$. fiorii stat. nov., A. sicula and A. trinacriae sp. nov. inside the genus Aphaenogaster is difficult to assess, considering the currently poor knowledge of the phylogenetic relationships inside the genus. On this topic, we stress the importance of using sexuals, and in particular males, rather than only workers, to infer phylogenetic relationships between species through morphological characters. While worker morphology can show a strong tendency towards evolutionary convergence (WARD 2007), the very different biology of males (PASSERA \& ARON 2005) may not generally favor this condition as much. However, males are far less easily collected and consequently they have been overlooked in most myrmecological taxonomic studies, to the extent that they remain undescribed for many taxa. Important exceptions are represented by the studies of Agosti (1990), BARden et al. (2017), Boudinot (2015), Deyrup et al. (2004), Eguchi et al. (2006), Fisher \& SMith (2008), GotzeK et al. (2012), Lapolla et al. (2012), MacGown et al. (2014), Seifert (2012), SEIFERT et al. (2016), Wagner et al. (2017), and Yoshimura \& Fisher (2007, 2009, 2011, 2012). Male morphology represented a clarifying element in our investigation, distancing $A$. fiorii stat. nov., A. sicula and $A$. trinacriae sp. nov. from $A$. subterranea s. 1. Superficial similarities between workers and queens may in fact be easily explained by convergent evolution. The same consideration could be made for $A$. crocea $\mathrm{s}$. 1. which has been considered to be close to $A$. subterranea (BERNARD 1953, CAGNIANT 1966, SCHEMBRI \& COLlingwoOd 1981, BOER 2013) despite the differences between the males (see CAGNIANT 1966) which were highlighted only once (CAGniant 1987). The definition of the A. subterranea species group given by Schulz (1994) and BOER (2013) was based entirely on worker morphology. In our opinion, it probably defines a polyphyletic group and must therefore be rejected. Recently, SALATA \& BOROWIEC (2018a) claimed that males inside the $A$. gibbosa species group are still unknown except for $A$. gibbosa and $A$. muschtaidica Emery, 1908. On the contrary, we would like to note that they are all known: A. theryi Santschi, 1923 (see Cagniant 1986, 1996), A. italica (see Emery 1916), 
A. striativentris Forel, 1895 (see TINAUT \& JiMÉNEZ RoJAS 1990; Antweb specimen KG00801), A. mauritanica Dalla Torre, 1893 (see SANTSChi 1932, CAGNiAnt 1987 - some differences between the drawings of the two authors), $A$. nadigi Santschi, 1923 (see Cagniant 1987). The male of the recently described $A$. ulibeli Gómez \& Espadaler, 2018 is also known (Gómez et al. 2018). Some differences between males of these species may be worth a more detailed evaluation. However, in general terms they appear as a morphologically homogeneous group. Males of $A$. fiorii stat. nov., A. sicula, A. trinacriae sp. nov. and A. crocea s. 1 . are clearly much more similar to the males of the aforementioned $A$. gibbosa group than to those of $A$. subterranea s. 1 . (as noted by CAGniant (1987) for $A$. crocea). Still, notable incongruences in male morphology homogeneity inside the currently recognized Aphaenogaster species groups are not limited to the A. subterranea species group. For example, the definition of the $A$. splendida species group as per BOER (2013), Borowiec \& SAlata (2014) and SAlata \& BorowIEC (2018a) seems no less problematic and completely overlooks males. It comprises A. cardenai Espadaler, 1981, A. muelleriana Wolf, 1915, A. ovaticeps (Emery, 1898), A. rugosoferruginea Forel, 1889, A. splendida and A. strioloides, but striking differences emerge when comparing the males of $A$. splendida (see EMERy 1908), A. cardenai (see Tinaut 1986), and $A$. strioloides (see SANTSCHI 1923). It is to be noted that recently $A$. cardenai has even been suspected to belong to another unrecognized genus rather than to Aphaenogaster (GómEz et al. 2018). Male morphology was also overlooked in the comparisons proposed by Schulz (1994) when describing A. graeca Schulz, 1994, and further examples could probably be found. According to Scupola (2017), the study of male morphology could also be useful in clarifying the currently confused situation of A. muelleriana and A. ovaticeps.

In conclusion, a broad revision of the Mediterranean Aphaenogaster, aided by the use of molecular data, is surely required in order to establish a reliable framework of phylogenetic relationships among the species. Actually, only a small number of Mediterranean species have been subjects of molecular studies (BRANSTETTER et al. 2016 , Lorite et al. 2017, Gómez et al. 2018, Centorame et al. 2018). However, morphological elements suggest that $A$. fiorii stat. nov., A. trinacriae sp. nov. and $A$. sicula are not part of any already established species group and are not closely related with any other European species. On the contrary, the morphology of their three castes convincingly relate them to several taxa from the Maghreb: $A$. crocea crocea, A. crocea croceoides, A. crocea lenis, A. crocea splendidoides, $A$. faureli and $A$. strioloides. Among these taxa, A. crocea is a superspecies (CAGNIANT 1996) awaiting a revision. Its subspecies croceoides and splendidoides were earlier treated as species by ScHULz (1994) and, along with the subspecies lenis, may all deserve to be elevated to species-rank in the future. Aphaenogaster faureli is a former subspecies of $A$. crocea that was elevated to species-rank by CAGNiAnt (1970). Finally, $A$. strioloides was first considered to be a subspecies of $A$. subterranea (FOREL 1890), then a subspecies of $A$. gibbosa (EMERY 1908), and finally a member of the $A$. splendida species group (SCHULZ 1994, Salata \& Borowiec 2018a), but it shows notable differences from the latter as partly discussed before. Since records of $A$. strioloides from Greece and Spain were likely a result of misidentification (Borowiec \& SAlata 2012; X. Espadaler pers. comm.), A. strioloides seems to be limited to the Maghreb as A. crocea s. 1. and A. faureli. Aphaenogaster crocea s. 1., A. faureli and $A$. strioloides all share yellowish to ferruginous workers with a similar shape and body proportions, whose sculpture and color are clearly distinct from those of the A. gibbosa species group. Among the Mediterranean fauna, their males are most similar to the A. gibbosa species group but are less gibbous and generally more lightly colored. Aphaenogaster hesperia, considered a Canarian endemic, probably belongs to the same group, but is currently only known from worker material (and it has become very rare according to BARQUín 1981).

Further investigations are needed to test the hypothesis of a possible $A$. crocea species group among the Mediterranean Aphaenogaster that would range from the Maghreb (and perhaps Canary Islands) to Sicily, Malta and Southern Italy. In particular, it would be worth to investigate the relationship between these species and those of the A. gibbosa group. Anyway, the presence of Maghrebian elements in the Sicilian fauna is known since the earliest documented history of the latter (MASINI \& SARÀ 1998) and represents a well-known biogeographical element of the region (LA GRECA 1957, 1961, 1990, 1995; MASSA et al. 2011). The Sicilian and Maltese myrmecofaunas currently share many taxa with the Maghreb (e.g. Camponotus barbaricus Emery, 1905, C. ruber Emery, 1925, etc.). While the last unanimously accepted terrestrial connection between Sicily and Africa occurred in the Messinian salinity crisis, new evidence suggests the existence of more recent connections (GIOvANNOTTI et al. 2007, STÖCK et al. 2008, LÁZARo et al. 2011, TroiA et al. 2012). In any case, the Maghrebian coasts are supposed to have been much closer to Sicily during the past glacial events (SHACKLETon et al. 1984). To this regard, Aphaenogaster species with functionally flying sexuals could possibly possess a dispersal capability sufficient to overcome such distances, especially if aided by favorable winds. Dispersion of taxa and genes has occurred both from the Maghreb to the Siculo-Maltese archipelago and from the Siculo-Maltese archipelago to the Maghreb (Hilpod et al. 2011, TroiA et al. 2012). Still, the absence of species similar to $A$. fiorii stat. nov., $A$. sicula and $A$. trinacriae sp. nov. in peninsular Italy and Europe, the large number of morphologically closely related species in the Maghreb, convincingly suggest a Maghrebian origin of the three entities. This is also coherent with the fact that the Maghreb is considered one of the two biodiversity centers of the genus in the Mediterranean basin as well as with its strong tendency to form allopatric endemics (BOWORIEC \& SALATA 2014).

\section{Acknowledgments}

We are grateful to the curators Roberto Poggi and Maria Tavano (MSNG) for allowing loans of the type specimens. We also wish to thank Daniel Cherix (MZLS), Bernhard Merz (MHNG), Fabrizio Rigato (MSNM), Adriano Zanetti 
and Antonio Scupola (MSNV) for the access to the respective museum collections, and Stephen P. Schembri (SSLM) for allowing us to access his personal collection. We also thank Ignazio Sparacio (Palermo) for the identification of Scydmaenus rufus specimens found inside a nest of $A$. trinacriae sp. nov.

\section{References}

AGNESI V., MACALUSO T., ORRÙ P. \& ULZEGA A. 1993: Paleogeografia dell'arcipelago delle Egadi (Sicilia) nel Pleistocene superiore, Olocene. Il Naturalista Siciliano 17: 3-22.

AGOSTI D. 1990: Review and reclassification of Cataglyphis (Hymenoptera, Formicidae). Journal of Natural History 24: 1457-1505.

ALICATA A. 1999: Sistematica ed ecoetologia delle specie silvicole di Aphaenogaster Mayr, 1853 (Hymenoptera, Formicidae) in Sicilia. Doctoral dissertation, University of Catania, Catania, $67 \mathrm{pp}$.

ANTWEB 2018: Available from: https://www.antweb.org/description do? subfamily $=$ myrmicinae $\&$ genus $=$ aphaenogaster $\&$ rank $=$ genus. (Accessed 16 August 2018.)

BARDEN P., BOUDINOT B. \& LUCKY A. 2017: Where fossils dare and males matter: combined morphological and molecular analysis untangles the evolutionary history of the spider ant genus Leptomyrmex Mayr (Hymenoptera: Dolichoderinae). Invertebrate Systematics 31: 765-780.

BARONI URBANI C. 1964: Studi sulla mirmecofauna d'Italia. II. Formiche di Sicilia. Atti dell' Accademia Gioenia di Scienze Naturali in Catania 16: 25-66.

BARONI URBANI C. 1968: Studi sulla mirmecofauna d'Italia. IV. La fauna mirmecologica delle isole Maltesi ed il suo significato ecologico e biogeografico. Annali del Museo Civico di Storia Naturale Giacomo Doria 77: 408-559.

BARONI URBANI C. 1971: Catalogo delle specie di Formicidae d'Italia (Studi sulla mirmecofauna d'Italia X). Memorie della Società Entomologica Italiana 50: 5-287.

BARQUÍN J. 1981: Las hormigas de Canarias. Taxonomía, ecología y distribución de los Formicidae. Colección Monografias (Secretariado de Publicaciones de la Universidad de La Laguna) 3: 1-584.

BERNARD F. 1953: Les fourmis du Tassili des Ajjer. [The ants of Tassili n'Ajjer]. Pp. 121-250. In: BERNARD F. (ed.): Mission scientifique au Tassili des Ajjer (1949). Volume I. Recherches zoologiques et médicales. P. Lechevalier, Paris, $302 \mathrm{pp}$

BERNARD F. 1958: Les fourmis des Îles Pelagie. Comparaison avec d'autres faunes insulaires. Rivista di Biologia Coloniale 16: 67-79.

BOER P. 2013: Revision of the European ants of the Aphaenogaster testaceopilosa-group (Hymenoptera: Formicidae). Tijdschrift voor Entomologie 156: 57-93.

BOLTON B. 1995: A taxonomic and zoogeographical census of the extant ant taxa (Hymenoptera: Formicidae). Journal of Natural History 29: $1037-1056$.

BONFIGLIO L., MANGANO G., MARRAA. C., MASINI F., PAVIAM. \& PETRUSO D. 2002: Pleistocene calabrian and sicilian bioprovinces. Geobios 35: 29-39.

BOROWIEC L. 2014: Catalogue of ants of Europe, the Mediterranean Basin and adjacent regions (Hymenoptera: Formicidae). Genus 25: $1-340$.

BOROWIEC L. \& SALATA S. 2012: Ants of Greece - checklist, comments and new faunistic data (Hymenoptera: Formicidae). Genus 23: $461-563$.

BOROWIEC L. \& SALATA S. 2014: Review of Mediterranean members of the Aphaenogaster cecconii group (Hymenoptera: Formicidae), with description of four new species. Zootaxa 3861: 40-60.

BOROWIEC L. \& SALATA S. 2017: Ants of the Peloponnese, Greece (Hymenoptera: Formicidae). Polish Journal of Entomology 86: 193-236.

BOUDINOT B. E. 2015: Contributions to the knowledge of Formicidae (Hymenoptera, Aculeata): a new diagnosis of the family, the first global male-based key to subfamilies, and a treatment of early branching lineages. European Journal of Taxonomy 120: 1-62.

BRANSTETTER M. G., LONGINO J. T., REYES-LÓPEZ J., SCHULTZ T. R. \& BRADY S. G. 2016: Into the tropics: phylogenomics and evolutionary dynamics of a contrarian clade of ants. bioRxiv http:// dx.doi.org/10.1101/039966.

CAGNIANT H. 1966: Nouvelle description d'Aphaenogaster (Attomyrma) crocea (André) Hyménoptère Formicidae. Représentation des trois castes. Notes biologiques. Bulletin de la Société Zoologique de France 91: 61-69.

CAGNIANT H. 1969: Description d'Aphaenogaster crocea faureli n. subsp. d'Algérie (Hym. Formicidae, Myrmicinae). Bulletin de la Société Zoologique de France 73: 232-235.

CAGNIANT H. 1970: Deuxième liste de fourmis d'Algérie récoltées principalement en forêt. (1re partie). Bulletin de la Société d'Histoire Naturelle de Toulouse 105: 405-430.

CAGNIANT H, 1986: Contribution à la connaissance des fourmis marocaines: description des sexués et compléments à la définition de l'espèce Aphaenogaster theryi Santschi 1923 (Hyménoptères, Formicoidea, Myrmicidae). Bulletin de la Société d'Histoire Naturelle de Toulouse 122: 139-143.

CAGNIANT H. 1987: Aphaenogaster nadigi Santschi, bona species (n. status). EOS, Revista Española de Entomología 62: 31-43.

CAGNIANT H. 1996: Les Aphaenogaster du Maroc (Hymenoptera: Formicidae): clé et catalogue des espèces. Annales de la Société Entomologique de France 32: 67-85.

CENTORAME M., MOSCHELLA F., RUSSINI V. \& FANFANI A. 2018: DNA-barcoding of the Italian members of the Aphaenogaster testaceopilosa-group (Hymenoptera: Formicidae): hybridization and biogeographic hypothesis. Zoologischer Anzeiger 277: 121-130.

DEYRUP M. \& COVER S. 2004: A new species of Odontomachus ant (Hymenoptera: Formicidae) from inland ridges of Florida, with a key to Odontomachus of the United States. Florida Entomologist 87: $136-144$.

EGUCHI K., YOSHIMURA M. \& YAMANE S. 2006: The Oriental species of the ant genus Probolomyrmex (Insecta: Hymenoptera: Formicinae: Proceratiinae). Zootaxa 1376: 1-35.

EMERY C. 1908: Beiträge zur Monographie der Formiciden des paläarktischen Faunengebietes. (Hym.) (Fortsetzung.) III. Die mit Aphaenogaster verwandte Gattungengruppe. Deutsche Entomologische Zeitschrift 1908: 305-338.

EMERY C. 1915: Contributo alla conoscenza delle formiche delle isole italiane. Descrizioni di forme mediterranee nuove o critiche. Annali del Museo Civico di Storia Naturale Giacomo Doria 46: 244-270.

EMERY C. 1916: Fauna entomologica italiana. I. Hymenoptera. - Formicidae. Bollettino della Società Entomologica Italiana 47: 79-275.

EMERY C. \& FOREL A. 1879: Catalogue des Formicides d'Europe. Mitteilungen der Schweizerischen Entomologischen Gesellschaft 5: 441-481.

FOREL A. 1890: Fourmis de Tunisie et de l'Algérie orientale recoltees et decrites par Auguste Forel. Annales de la Société Entomologique de Belgique 34: 61-76.

FISHER B. L. \& SMITH M. A. 2008: A revision of Malagasy species of Anochetus Mayr and Odontomachus Latreille (Hymenoptera: Formicidae). PLoS One 3(5)(e1787): 1-23.

GIOVANNOTTI M., CERIONI P. N., KALBOUSSI M., APREA G. \& CAPUTO V. 2007: Phylogeographic inferences from the mtDNA variation of the three-toed skink, Chalcides chalcides (Reptilia: Scincidae). Journal of Experimental Zoology Part B: Molecular and Developmental Evolution 308: 297-307.

GÓMEZ K. 2017: Two species of exotic ants (Hymenoptera: Formicidae) new to Malta. Boletín de la Sociedad Entomológica Aragonesa 61: 233-235

GÓMEZ K., MARTIÍNEZ D. \& ESPADALER X. 2018: Phylogeny of the ant genus Aphaenogaster (Hymenoptera: Formicidae) in the Iberian Peninsula, with the description of a new species. Sociobiology 65: $215-224$

GOTZEK D., BRADY S. G., KALLAL R. J. \& LAPOLLA J. S. 2012 The importance of using multiple approaches for identifying emerging invasive species: The case of the raspberry crazy ant in the United States. PLoS One 7(9)(e45314): 1-10.

GRANDI G. 1935: Contributi alla conoscenza degli Imenotteri Aculeati. XV. Bollettino dell 'Istituto di Entomologia dell'Università di Bologna 26: 81-255.

HILPOLD A., SCHÖNSWETTER P., SUSANNAA, GARCIA-JACAS N. \& VILATERSANA R. 2011: Evolution of the central Mediterranean Centaurea cineraria group (Asteraceae): evidence for relatively recent, allopatric diversification following transoceanic seed dispersal. Taxon 60: 528-538.

HÖLLDOBLER B. \& WILSON E. O. 1990: The Ants. Springer Verlag, Berlin, $732 \mathrm{pp}$

KARAMAN M. G. 2011: Katalog faune mrava (Hymenoptera, Formicidae) Crne Gore. (A catalogue of the ants (Hymenoptera, Formicidae) of Montenegro.) Catalogues 3, Volume 2, Montenegrin Academy of Sciences and Arts, Podgorica, 140 pp. (in Montenegrin, English summary). 
KUTTER H. 1927: Ein myrmekologischer Streifzug durch Sizilien. Folia Myrmecologica et Termitologica 1: 135-136.

LA GRECA M. 1957: Considerazioni sull'origine della fauna siciliana. Italian Journal of Zoology 24: 593-631.

LA GRECA M. 1961: Considerazioni sull'origine e la costituzione della fauna di Sicilia. Archivio Botanico e Biogeografico Italiano 6: 2-23.

LA GRECA M. 1990: The insect biogeography of west Mediterranean islands. Atti dei Convegni Lincei 85: 459-468.

LA GRECA M. 1995: Il concetto di fauna e le caratteristiche della fauna italiana. Atti dei Convegni Lincei 118: 13-28.

LA MANTIA T. 2009: La biodiversità delle formazioni naturali e seminaturali in Sicilia: cambiamenti e ipotesi di gestione. Pp. 199-204. In Atti del Terzo Congresso Nazionale di Selvicoltura. Taormina (ME), 16-19 ottobre 2008. Accademia Italiana di Scienze Forestali, Firenze.

LAPOLLA J. S., KALLAL R. J. \& BRADY S. G. 2012: A new ant genus from the Greater Antilles and Central America, Zatania (Hymenoptera: Formicidae), exemplifies the utility of male and molecular character systems. Systematic Entomology 37: 200-214.

LÁZARO E. M., HARRATH A. H., STOCCHINO G. A., PALA M., BAGUÑ̇̀ J. \& RIUTORT M. 2011: Schmidtea mediterranea phylogeography: an old species surviving on a few Mediterranean islands? BMC Evolutionary Biology 11(274): 1-15.

LEBAS C., GALKOWSKI C., BLATRIX R. \& WEGNEZ P. 2016: Fourmis d'Europe Occidentale. Le premier guide complet d'Europe. Delachaux et Niestlé, Paris, France, 416 pp.

LI VIGNI I. 2014: Interactions between ants and diaspores of flowering plants (myrmecochory) in Sicily (Southern Italy): an important ecosystem function of the Mediterranean basin. Doctoral dissertation, University of Catania, Catania, $179 \mathrm{pp}$.

LORITE P., MUÑOZ-LÓPEZ M., CARRILLO J.A., SANLLORENTE O., VELA J., MORA P., TINAUT A., TORRES M.I. \& PALOMEQUE T. 2017: Concerted evolution, a slow process for ant satellite DNA: study of the satellite DNA in the Aphaenogaster genus (Hymenoptera, Formicidae) Organisms Diversity and Evolution 17: 595-606.

MACGOWN J. A., BOUDINOT B., DEYRUP M. \& SORGER D. M. 2014: A review of the Nearctic Odontomachus (Hymenoptera: For micidae: Ponerinae) with a treatment of the males. Zootaxa 3802. $515-552$.

MASINI F. \& SARÀ M. 1998: Asoriculus burgioi sp. nov. (Soricidae, Mammalia) from the Monte Pellegrino faunal complex (Sicily). Acta Zoologica Cracoviensis 41: 111-124.

MASSA B., SBORDONI V. \& VIGNA TAGLIANTIA. 2011: La Biogeografia della Sicilia: considerazioni conclusive sul XXXVII Congresso della Società Italiana di Biogeografia. Biogeographia - The Journal of Integrative Biogeography 30: 685-694.

O'KEEFE S. T. 2000: Ant-like stone beetles, ants, and their associations (Coleoptera: Scydmaenidae; Hymenoptera: Formicidae; Isoptera). Journal of the New York Entomological Society 108: 273-303.

PARKER J. 2016: Myrmecophily in beetles (Coleoptera): evolutionary patterns and biological mechanisms. Myrmecological News 22 : 65-108.

PASSERA L. \& ARON S. 2005: Les fourmis: comportement, organisation sociale et évolution. Les presses Scientifiques du CNRC, Ottawa, Canada, $480 \mathrm{pp}$.

PETROV I. Z. 2000: Checklist of the myrmecofauna (Formicidae, Hymenoptera) of Yugoslavia. Archives of Biological Science Belgrade 52: $243-249$.

SALATA S. \& BOROWIEC L. 2018a: Redescription of Aphaenogaster muschtaidica Emery, 1908 with a key to gibbosa species group. Asian Myrmecology 10(e010002): 1-16.

SALATA S. \& BOROWIEC L. 2018b: Three ant species (Hymenoptera: Formicidae) new to the fauna of Malta. Boletín de la Sociedad Entomológica Aragonesa 63: 132-134.

SANTSCHI F. 1911: Formicides de diverses provenances. Annales de la Société Entomologique de Belgique 55: 278-287.

SANTSCHI F. 1932: Études sur quelques Attomyrma paléarctiques. Mitteilungen der Schweizerischen Entomologischen Gesellschaft 15: 338-346.

SCHEMBRI S. P. \& COLLINGWOOD C. A. 1981: A revision of the myrmecofauna of the Maltese Islands (Hymenoptera, Formicidae). Annali del Museo Civico di Storia Naturale Giacomo Doria 83: 417-442.

SCHIFANI E. \& ALICATA A. 2018: Exploring the myrmecofauna of Sicily: thirty-two new ant species recorded, including six new to Italy and many new aliens (Hymenoptera, Formicidae). Polish Journal of Entomology 87: 323-348.
SCHULZ A. 1994: Aphaenogaster graeca nova species (Hym: Formicidae) aus dem Olymp-Gebirge (Griechenland) und eine Gliederung der Gattung Aphaenogaster. Beiträge zur Entomologie 44: 417-429.

SCUPOLA A. 2009: Le formiche delle Isole Egadi (Sicilia) (Hymenoptera, Formicidae). Bollettino del Museo Civico di Storia Naturale di Verona 33: 97-103.

SCUPOLA A. 2017: Aphaenogaster muelleriana Wolf, 1915 (Hymenoptera Formicidae) in Salento (South East Italy). Biodiversity Journal 8: $3-8$.

SEIFERT B. 2012: Clarifying naming and identification of the outdoor species of the ant genus Tapinoma Förster, 1850 in Europe north of the Mediterranean region with description of a new species. Myrmecological News 16: 139-147.

SEIFERT B., D'EUSTACCHIO D., KAUFMANN B., CENTORAMEM. \& MODICA M. 2017: Four species within the supercolonial ants of the Tapinoma nigerrimum complex revealed by integrative taxonomy (Hymenoptera: Formicidae). Myrmecological News 24: 123-144.

SHACKLETON J. C., VAN ANDEL T. H. \& RUNNELS C. N. 1984: Coastal paleogeography of the central and western Mediterranean during the last 125,000 years and its archaeological implications. Journal of Field Archaeology 11: 307-314.

STOCH F. \& VIGNA TAGLIANTI A. 2006. The chorotypes of the Italian fauna. Pp. 25-28. In: RUFF O S. \& STOCH F. (eds.): Checklist and distribution of the Italian fauna. Memorie del Museo Civico di Storia naturale di Verona 16: 1-307.

STÖCK M., SICILIAA., BELFIORE N. M., BUCKLEY D., LO BRUTTO S., LO VALVO M. \& ARCULEO M. 2008: Post-Messinian evolutionary relationships across the Sicilian channel: mitochondrial and nuclear markers link a new green toad from Sicily to African relatives. BMC Evolutionary Biology 8(56): 1-19.

TINAUT A. 1986: Descripción del macho de Aphaenogaster cardenai Espadaler, 1981 (Hymenoptera, Formicidae). Miscellània Zoològica 9: 245-249.

TINAUT A. \& JIMÉNEZ ROJAS J. 1991: Redescripción de Aphaenogaster striativentris Forel, 1895 y consideraciones sobre su polimorfismo (Hymenoptera, Formicidae). EOS, Revista Española de Entomología 66: $117-126$.

TROIAA., RAIMONDO F. M. \& GERACIA. 2012: Does genetic population structure of Ambrosina bassii L. (Araceae, Ambrosineae) attest a post-Messinian land-bridge between Sicily and Africa? Flora-Morphology, Distribution, Functional Ecology of Plants 207: 646-653.

WAGNER H. C., ARTHOFER W., SEIFERT B., MUSTER C., STEINER F. M. \& SCHLICK-STEINER B. C. 2017: Light at the end of the tunnel: Integrative taxonomy delimits cryptic species in the Tetramorium caespitum complex. Myrmecological News 25: 95-129.

WARD P. S. 2007: Phylogeny, classification, and species-level taxonomy of ants. Zootaxa 1668: 549-563.

WARD P. S. 2011: Integrating molecular phylogenetic results into ant taxonomy (Hymenoptera: Formicidae). Myrmecological News 15: 21-29.

WARD P. S., BRADY S. G., FISHER B. L. \& SCHULTZ T. R. 2014 The evolution of myrmicine ants: phylogeny and biogeography of a hyperdiverse ant clade (Hymenoptera: Formicidae). Systematic Entomology 40: 61-81.

YOSHIMURA M. \& FISHER B. L. 2007: A revision of male ants of the Malagasy region (Hymenoptera: Formicidae): Key to subfamilies and treatment of the genera of Ponerinae. Zootaxa 1654: 21-40.

YOSHIMURA M. \& FISHER B. L. 2009: A revision of male ants of the Malagasy region (Hymenoptera: Formicidae): Key to genera of the subfamily Proceratiinae. Zootaxa 2216: 1-21.

YOSHIMURA M. \& FISHER B. L. 2011: A revision of male ants of the Malagasy region (Hymenoptera: Formicidae): Key to genera of the subfamily Dolichoderinae. Zootaxa 2794: 1-34.

YOSHIMURA M. \& FISHER B. L. 2012: A revision of male ants of the Malagasy Amblyoponinae (Hymenoptera: Formicidae) with resurrections of the genera Stigmatomma and Xymmer. PLoS One 7(3)(e33325): 1-23.

Editorial note. This paper was originally published on-line on $24^{\text {th }}$ January 2019 but included pre-final versions of all plates and thus would cause incorrect understanding of the species included. To prevent confusion and to comply the requirements of ICZN on on-line publishing, we corrected the plates in the current version, updated the date of publication in ZooBank to $28^{\text {th }}$ January 2019 , and replaced the original file in Biotaxa for the current one. Therefore, $28^{\text {th }}$ January 2019 must be understood as the publication date of the paper for the purpose of zoological nomenclature. 